Science

March 2013, Volume 339 Issue 6125 Pages 1305-1308

http://dx.doi.org/10.1126/science. 1229240

http://archimer.ifremer.fr/doc/00176/28767/

(C) 2013, American Association for the Advancement of Science

\title{
Evidence for Microbial Carbon and Sulfur Cycling in Deeply Buried Ridge Flank Basalt
}

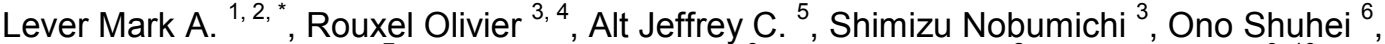 \\ Coggon Rosalind M. ${ }^{7}$, Shanks Wayne C., lii ${ }^{8}$, Lapham Laura ${ }^{2}$, Elvert Marcus ${ }^{9,10}$, \\ Prieto-Mollar Xavier ${ }^{9,10}$, Hinrichs Kai-Uwe ${ }^{9,10}$, Inagaki Fumio ${ }^{11}$, Teske Andreas ${ }^{1}$
}

${ }^{1}$ Univ N Carolina, Dept Marine Sci, Chapel Hill, NC 27599 USA.

${ }^{2}$ Aarhus Univ, Dept Biosci, Ctr Geomicrobiol, DK-8000 Aarhus C, Denmark.

${ }^{3}$ Woods Hole Oceanog Inst, Woods Hole, MA 02543 USA.

${ }^{4}$ IFREMER, Ctr Brest, F-29280 Plouzane, France.

${ }^{5}$ Univ Michigan, Dept Earth \& Environm Sci, Ann Arbor, MI 48109 USA.

${ }_{7}^{6}$ MIT, Dept Earth Atmospher \& Planetary Sci, Cambridge, MA 02139 USA.

${ }^{7}$ Univ London Imperial Coll Sci Technol \& Med, Dept Earth Sci \& Engn, London SW7 2AZ, England.

${ }^{8}$ US Geol Survey, Denver, CO 80225 USA.

${ }^{9}$ Univ Bremen, Dept Geosci, Organ Geochem Grp, D-28334 Bremen, Germany.

${ }^{10}$ Univ Bremen, MARUM Ctr Marine Environm Sci, D-28334 Bremen, Germany.

11 Japan Agcy Marine Earth Sci \& Technol, Kochi Inst Core Sample Res, Geomicrobiol Grp, Nanko Ku, Kochi 7838502, Japan.

*Corresponding author : email address : mark.lever@biology.au.dk ; teske@email.unc.edu

\begin{abstract}
:
Sediment-covered basalt on the flanks of mid-ocean ridges constitutes most of Earth's oceanic crust, but the composition and metabolic function of its microbial ecosystem are largely unknown. By drilling into 3.5-million-year-old subseafloor basalt, we demonstrated the presence of methane-and sulfurcycling microbes on the eastern flank of the Juan de Fuca Ridge. Depth horizons with functional genes indicative of methane-cycling and sulfate-reducing microorganisms are enriched in solid-phase sulfur and total organic carbon, host delta C-13- and delta S-34-isotopic values with a biological imprint, and show clear signs of microbial activity when incubated in the laboratory. Downcore changes in carbon and sulfur cycling show discrete geochemical intervals with chemoautotrophic delta $\mathrm{C}-13$ signatures locally attenuated by heterotrophic metabolism.
\end{abstract}

\section{Main text}

Subseafloor basaltic crust represents the largest habitable zone by volume on Earth (1). Chemical reactions of basalt with seawater flowing through fractures release energy that may support chemosynthetic communities. Microbes exploiting these reactions are known from basalt exposed at the seafloor, where the oxidation of reduced sulfur $(\mathrm{S})$ and iron $(\mathrm{Fe})$ from basalt with dissolved oxygen and nitrate from seawater supports high microbial biomass and diversity $(\underline{2}, \underline{3})$. Multiple lines of indirect evidence that include textural alterations (4), depletions in $\delta^{34} \mathrm{~S}$-pyrite $\left(\mathrm{FeS}_{2}\right)(\underline{5})$ and $\delta^{13} \mathrm{C}$-dissolved inorganic carbon (DIC) ( $\underline{6})$, and DNA sequences from 
borehole observatories $(7,8)$ suggest active microbial communities in subseafloor basalt.

We combined sequencing of genes diagnostic of microbial methane- and Scycling with geochemical and isotopic analyses of C- and S-pools and laboratorybased incubations to directly identify microbial ecosystem components in deep subseafloor basalt. The 3.5 million-year-old basement at site U1301 was sampled during Integrated Ocean Drilling Program (IODP) Expedition 301 in 2004 (Fig. S1) (9). Site U1301 off the eastern flank of the Juan de Fuca ridge, is covered by a 265-m thick sediment layer and lies $\sim 2 \mathrm{~km}$ south of ODP Site 1026, which it resembles in temperature profile, lithology, and sediment chemistry (9). Given anticipated poor recovery due to brecciation of the upper basement (265-350 meters below seafloor; mbsf), coring was restricted to an interval of pillow basalts and massive lavas (351$583 \mathrm{mbsf})$. Sulfate concentrations $(\sim 16 \mathrm{mM})$ and vein carbonates indicate basalt fluids are derived from seawater, which enters $\sim 80 \mathrm{~km}$ south at Grizzly Bare outcrop and discharges near U1301, at Baby Bare and Mama Bare outcrops (9, 10; Fig. S1B). Yet, the basement at U1301 differs from seafloor-exposed basalt in its uniformly high temperature $\left(\sim 64^{\circ} \mathrm{C}\right)(9)$ and lack of fresh photosynthesis-derived organic matter, dissolved oxygen and nitrate $(7,11)$. These conditions preclude oxygen- or nitratedependent microbial S- and Fe-oxidation (12), but may enable growth of anaerobes, such as sulfate reducers and methanogens, which use sulfate and DIC as electron acceptors.

We sequenced genes encoding the $\alpha$ subunit of methyl coenzyme $\mathrm{M}$ reductase ( $m c r A)$, a gene unique to methanogens and anaerobic methane-oxidizers (13), and the $\beta$ subunit of dissimilatory sulfite reductase $(d s r B)$, a gene found in sulfate- and sulfite-reducing microbes (14), to indicate the presence of methane-cycling and sulfate-reducing microbes. We detect $m c r A$ in 5 of the 10 samples and $d s r B$ in 4 of the 
6 samples tested (Table S1), suggesting that these metabolisms are present in this environment.

The phylogenetic diversity of $m c r A$ genes we identified is restricted to two groups: the Juan de Fuca Methanogen Group (JdFMG), which falls into an uncultivated cluster within the Methanosarcinales, and anaerobic methane-oxidizing archaea (ANME-1; Fig. 1A). Close relatives of the JdFMG have been identified from paddy and wetland soil $(15,16)$, and have also been found in marine habitats, including Juan de Fuca Ridge hydrothermal vent chimneys and seafloor-exposed basalt $\sim 100 \mathrm{~km}$ west of U1301 (Fig. S2) $(17,18)$. ANME-1 occur widely in marine sediments and methane seeps, and are believed to gain energy from the anaerobic oxidation of methane (AOM) (19). Two distinct ANME phylotypes occur at U1301, one closely related to ANME-1 from methane seeps, and another clustering with only one other sequence, from subseafloor sediment (Fig. S3). We detected JdFMG in 4, and ANME-1 in 3 out of 10 basalt samples. Two samples contained both groups (Table S1).

The phylogenetic diversity of $d s r B$ in these samples is limited to one group, the Juan de Fuca Sulfate Reducing Group (JdFSRG), which falls into Cluster IV, a deeply-branching $d s r B$ cluster without cultured members, first reported from hydrothermal sediment (Fig. 1B and S4, Table S1) (20). Remarkably, the only other $d s r$ sequences reported so far from the subseafloor - in sediment of the Peru Margin (21) - also fall into this cluster, which is widespread in shallow marine sediment and terrestrial aquifers.

We studied solid-phase S-pools by analyzing acid-volatile sulfide (AVS), chromium-reducible $\mathrm{S}(\mathrm{CRS})$, and sulfate-S $\left(\mathrm{SO}_{4}-\mathrm{S}\right)$ as a proxy to redox processes and correlate to microbial metabolisms $(5,22)$. We only found $d s r B$ sequences in a 
102

103

104

relatively reduced 'intermediate depth interval' ( 430-520 mbsf, 14R-26R), in samples with AVS as the main S pool in alteration halos (14R-1-11) - the visually conspicuous zone surrounding fractures (Fig. S1C) - or in host rock (17R-170, 20R-157, 23R-2-21; Fig. S5, Table S1). Samples from this interval have higher AVS, CRS, and total S (Fig. S5, Table S2), contain large pyrite fronts (14R-1-65P, 15R-4-142P; Fig. S5), and have lower $\delta^{34} \mathrm{~S}-\mathrm{AVS},-\mathrm{CRS}$, and $-\mathrm{SO}_{4}-\mathrm{S}$, compared to the more oxidized upper (1R-12R) and lower coring intervals (30R-36R; Fig. S6, Table S1). Consistent with higher $\mathrm{Fe}^{3+} / \mathrm{Fe}^{\text {Total }}$ ratios, which indicate halos to be more oxidized than host rock (Table S1), pyrite is generally absent from halos or veins. Outside the intermediate depth interval, the near absence of pyrite from host rock, and mixed clay-Fe-oxyhydroxide-dominated halos and veins are further evidence of pervasive oxidative alteration.

We analyzed the $\delta^{34} \mathrm{~S}$ signature of pyrite grains to examine micro- and macroscale variations in microbial S-cycling (Tables S1 and S3, Fig. 2). Though variable, the $\delta^{34}$ S-pyrite grains (-72.4 to $1.2 \%$; Table $S 3$ ) are typically lower than those of AVS (-9.3 to $-0.2 \%$ ), CRS (-13.7 to $0 \%$ ), $\mathrm{SO}_{4}-\mathrm{S}$ (-6.5 to $0 \%$ ), mantle $\mathrm{S}$ $(0 \%$ ) (5), dissolved sulfate in bottom sediments at ODP Site $1026(+30 \%$ ) (23), or seawater (+21\% ; Fig. 2). Locally, the $\delta^{34} \mathrm{~S}$ of pyrite grains reach very negative values $\left(-72 \%\right.$ o), consistent with the addition of highly ${ }^{34}$ S-depleted secondary sulfide to basement rock (22). These low $\delta^{34} \mathrm{~S}$-pyrite values indicate single-step sulfate reduction (24) or repeated cycles of sulfate reduction and S oxidation (25). The cooccurrence of low $\delta^{34} \mathrm{~S}$-pyrite, $d s r B$, and $m c r A$ of ANME-1 in two samples (14R-111, 17R-1-70) suggests local coupling between methane and S-cycling by sulfatedependent AOM.

Depth profiles of total organic carbon (TOC) content, $\delta^{13} \mathrm{C}$-TOC, and $\delta^{13} \mathrm{C}$ carbonate at U1301B are consistent with functional gene- and ${ }^{34}$ S-data (Fig. 3). The 
TOC content is highest in the intermediate depth interval in cores with $m c r A, d s r B$, and low $\delta^{34}$ S-pyrite (Fig. 3A, Table S4). The $\delta^{13} \mathrm{C}$-TOC is in the range of dissolved organic C (DOC) in fluids from nearby 1026B and Baby Bare Springs (BBS; Fig. 3B, Table S4) and lower than seawater DOC (-21.1\%o; 6). The $\delta^{13} \mathrm{C}$-carbonate is higher than $\delta^{13} \mathrm{C}$-DIC at $1026 \mathrm{~B}$ or BBS (Fig. 3C, Table S5) and overlaps with $\delta^{13} \mathrm{C}$-DIC of bottom seawater $(-1.4 \% ; 10)$.

$\delta^{13} \mathrm{C}$-TOC values in the upper coring interval (4R-5R) and near the bottom (23R-26R; -34.6 to $-32.0 \%$ ) are close to $\delta^{13}$ C-DOC from nearby BBS (-34.6\%o; Fig. 3B). The absence of $\mathrm{O}_{2}$ and the high ${ }^{13} \mathrm{C}$-TOC depletion relative to carbonate $(\sim-30$ to $-35 \%$ ) suggest $\mathrm{C}$ fixation by the reductive acetyl CoA pathway - an anaerobic pathway found in all methanogens and acetogens, and certain sulfate and iron reducers (Fig. S7, Tables S6 and S7; 26). The presence of $d s r B$ but not $m c r A$ in these samples suggests that sulfate reducers or other groups, but not methanogens, produce this low $\delta^{13} \mathrm{C}$-TOC.

$\delta^{13} \mathrm{C}$-TOC at the top (2R) and in the intermediate depth interval (-28.4 to $21.6 \%$ ) are close to $\delta^{13} \mathrm{C}$-DOC from borehole 1026B (-26.1\%o, Fig. 3B; o). The ${ }^{13} \mathrm{C}-$ depletion relative to carbonate is lower than in the other layers $(\sim-20$ to $-26 \%$ ), but also falls in the range of the reductive acetyl CoA pathway (Table S7), and, consistent with $m c r A$ detection, could be impacted by autotrophic methanogenesis. In addition, elevated heterotrophic activity is possible, since degradation of chemoautotrophyderived OC, e.g. by AOM, methanogenesis or fermentation, would lower the $\delta^{13} \mathrm{C}$ carbonate and potentially raise the $\delta^{13} \mathrm{C}$-TOC. In fact, the lowest $\delta^{13} \mathrm{C}$-carbonate values (to $-5.1 \%$ o) were measured in the intermediate depth interval (18R; Fig. 3, Table S5), consistent with a locally significant input of IC from the degradation of chemoautotrophy-derived OC. The alternative explanation, enhanced breakdown of photosynthesis-derived OC in the intermediate depth interval, is unlikely given that 
154 sediment inclusions are absent (9). Similarly, influx of labile DOC or unaltered DIC

155 from seawater is incompatible with the 7-11 kyr greater DOC age compared to bottom

156 seawater and the 4-8\%o decrease in $\delta^{13} \mathrm{C}$-DIC along the flowpath from Grizzly Bare

157 outcrop to $1026 \mathrm{~B}$ and BBS, respectively $(6,10)$.

158

159

160

161

162

163

164

165

166

167

168

169

170

171

172

173

174

175

176

177

178

179

180

To rule out a fossil origin of functional genes and the chemical and isotopic signatures, we incubated pieces from the interior of three rock samples used for functional gene analyses (1R-1-79, 14R-1-11, 23R-2-21) at $65^{\circ} \mathrm{C}$ in anoxic, sulfaterich media containing $\mathrm{H}_{2}$, acetate, methanol, and dimethyl sulfide as energy substrates (Table S8). After two years, aliquots were transferred to fresh media, and incubated for another five years using triple-autoclaved basalt pieces as substrata. By then, low concentrations of ${ }^{13} \mathrm{C}$-depleted methane (-54 to $-65 \%$ ) had formed indicating the presence of active methanogenic microorganisms (Table S9).

The variability in $\delta^{34} \mathrm{~S}$-pyrite, $\delta^{13} \mathrm{C}$-TOC and $\delta^{13} \mathrm{C}$-carbonate indicates that micro- and macro-scale geochemical changes related to mineralogy, fracturing and/or fluid flow strongly influence microbial activity. These chemical microniches may explain the coexistence of sulfate reducers and methanogens at U1301 and in other igneous habitats, despite higher energy yields of sulfate reduction compared to methanogenesis (27). In addition, some methanogens can survive in the presence of sulfate reducers by consuming non-competitive methylated substrates (28). Since methanogenic substrate usage follows mcrA phylogeny (28), this explanation is consistent with the ability of a close relative of JdFMG to use methanol (16); it is also consistent with the production of biogenic methane in basalt incubations containing sulfate and methanol (Table S9, Fig. S8).

Inorganic electron donors used by sulfate reducers and methanogens, e.g. $\mathrm{H}_{2}$, are likely to derive from serpentinization reactions, whereby Fe(II) minerals, e.g. 
181 olivine $\left((\mathrm{Mg}, \mathrm{Fe})_{2} \mathrm{SiO}_{4}\right)$, which is abundant in several basalt horizons at U1301 (9,

182 Fig. S9, Tables S10, S11), are oxidized in abiotic reactions with seawater-derived

183 fluids (1). Organic electron donors, e.g. short-chain fatty acids and alcohols, are

184 probably produced by breakdown of autochthonous OC $(6,27,29)$ or Fischer-

185 Tropsch-type synthesis (30, Table S10). Targeted investigations of potential carbon

186 and energy sources will provide further insights to micro- and macroscale

187 heterogeneity of microbial C-and S-cycling, and thus contribute to a better

188 understanding of chemoautotrophic ecosystems within Earth's oceanic crust.

\section{References}

191 1. W. Bach, K. J. Edwards, Geochim. Cosmochim. Acta 67, 3871 (2003).

192 2. K. J. Edwards, T. M. McCollom, H. Konishi, P. R. Buseck. Geochim. $193 \quad$ Cosmochim. Acta 67, 2843 (2003).

194 3. C. M. Santelli et al., Nature 453, 653 (2008).

195 4. M. R. Fisk, S. J. Giovannoni, I. H. Thorseth, Science 281, 978 (1998).

196 5. O. Rouxel, S. Ono, J. Alt, D. Rumble, J. Ludden, Earth Planet. Sci. Lett. 268, $197 \quad 110(2008)$.

198 6. M. D. McCarthy et al., Nature Geosci 4, 32 (2011).

199 7. J. P. Cowen et al., Science 299, 120 (2003).

200 8. B. N. Orcutt et al., ISME J. 5, 692 (2011)

201 9. A. T. Fisher, T. Urabe, A. Klaus, Expedition 301 Scientists, Proc. IODP 301 $202 \quad$ (2005).

203 10. B. D. Walker, M. D. McCarthy, A. T. Fisher, T. P. Guilderson, Mar. Chem. $204 \quad \mathbf{1 0 8}, 123(2008)$.

205 11. C. G. Wheat et al., Geochem. Geophys. Geosyst. 11, 1 (2010).

206 12. A. Schippers, B. B. Jørgensen, Geochim. Cosmochim. Acta 66, 85 (2002). 
13. M. W. Friedrich, Meth. Enzymol. 397, 428 (2005).

14. M. Wagner, A. J. Roger, J. L. Flax, G. A. Brusseau, D. A. Stahl, Appl. Environ Microbiol. 75, 7086 (1998).

15. T. Lueders, K.-J. Chin, R. Conrad, M. Friedrich, Environ. Microbiol. 3, 194 (2001).

16. G. Zhang et al., Environ. Microbiol. 10, 1850 (2008).

17. F. Wang et al., Proc. Nat. Acad. Sci. U.S.A. 106, 4840 (2009).

18. O. U. Mason et al., ISME J. 3, 231 (2009).

19. K. Knittel, A. Boetius, Ann. Rev. Microbiol. 63, 311 (2009).

20. A. Dhillon, A. Teske, J. Dillon, D. A. Stahl, M. L. Sogin, Appl. Environ. Microbiol. 69, 2765 (2003).

21. G. Webster et al., FEMS Microbiol. Ecol. 58, 65 (2006).

22. S. Ono, N.S. Keller, O. Rouxel, J. C. Alt, Geochim. Cosmochim. Acta 87, 323 (2012).

23. M. D. Rudnicki, H. Elderfield, B. Spiro, Geochim. Cosmochim. Acta 65, 777 (2001).

24. M. S. Sim, T. Bosak, S. Ono, Science 333, 74 (2011).

25. D. E. Canfield, B. Thamdrup, Science 266, 1973 (1994).

26. A. L. Zerkle, C. H. House, S. L. Brantley, Am. J. Sci. 305, 467 (2005).

27. H.-T. Lin, J. P. Cowen, E. J. Olson, J. P. Amend, M. D. Lilley, Geochim. Cosmochim. Acta 85, 213 (2012).

28. W. B. Whitman, T. L. Bowen, D. R. Boone, The Prokaryotes 3, 165 (2006).

29. M. A. Lever, et al., Geomicrobiol. J. 27, 183 (2010).

30. T. M. McCollom, J. S. Seewald, Chem. Rev. 107, 382 (2007).

Supplementary online material references:

31. M. A. Lever et al., Geomicrobiol. J. 23, 517 (2006).

32. J. F. Biddle et al., Proc. Nat. Acad. Sci. U.S.A. 103, 3846 (2006). 
33. M. A. Lever, Ph.D. Dissertation. University of North Carolina at Chapel Hill, Chapel Hill, NC (2008).

34. W. Ludwig et al., Nucleic Acids Res. 32, 1363 (2004).

35. E. M. Ripley et al., Rev. Mineral. Geochem. 73, 9 (2011).

36. P. Craddock, O. Rouxel, L. Ball, W. Bach, Chem. Geol. 253, 102 (2008).

37. A. Delacour, G. L. Früh-Green, S. M. Bernasconi, P. Schaeffer, D. S. Kelley, Geochim. Cosmochim. Acta 72, 3681 (2008).

38. B. N. Popp, F. J. Sansone, T. M. Rust, D. A. Merritt, Anal. Chem. 67, 405 (1995).

39. C. H. House, J. W. Schopf, K. O. Stetter, Org. Geochem. 34, 345 (2003).

40. S. Sakata, J. M. Hayes, M. Rohmer, A. B. Hooper, M. Seemann, Org. Geochem. 39, 1725 (2008).

41. M. Könneke, J. S. Lipp, K.-U. Hinrichs, Org. Geochem. 48, 21 (2012).

42. K. L. Londry, D. J. Des Marais, Appl. Environ. Microbiol. 69, 2942 (2003).

43. K. L. Londry, L. L. Jahnke, D. J. Des Marais, Appl. Environ. Microbiol. 70, 745 (2004).

44. M. J. Alperin, T. M. Hoehler, Am. J. Sci. 309, 958 (2009).

45. A. Gittel, K. B. Sørensen, T. L. Skovhus, K. Ingvorsen, A. Schramm, Appl. Environ. Microbiol. 75, 7086 (2009).

46. B. O. Steinsbu et al., Int. J. Syst. Evol. Microbiol. 60, 2745 (2010).

Acknowledgments. We thank B. Jørgensen, M. Sogin and the IODP Expedition 301

Scientists for advice and support in this project. Funding was obtained from a

Schlanger Ocean Drilling Fellowship, a University of North Carolina Dissertation

Completion Fellowship, a Marie-Curie Intra-European Fellowship (\#255135; all to M.

Lever), the Danish National Research Foundation, the Max Planck Society (both to B. Jørgensen), Europole Mer (to O. Rouxel), the European Research Council Advanced

Grant DARCLIFE (to K.-U. Hinrichs), the NASA Astrobiology Institute Subsurface 
263 Biospheres (to A. Teske), the Japan Society for the Promotion of Science 264 (JSPS) Funding Program for Next Generation World-Leading Researchers (NEXT 265 Program; to F. Inagaki), and the National Science Foundation (NSF-OCE 0622949 266 and OCE 1129631 to J. Alt, OCE-0753126 to S. Ono and O. Rouxel, and NSF-ODP 2670727175 and NSF-STC for Dark Energy Biosphere Investigations to A. Teske). We 268 thank three anonymous reviewers for very helpful comments. The geochemical data 269 are available in the Supplementary Tables. Experimental procedures are described in 270 Supplementary Online Materials. The functional gene sequence data are available 271 from Genbank database (accession numbers GU182109 to GU182110, and JX465656 272 to JX465658). 


\section{FIGURES}

274 Figure 1. Phylogenetic trees of functional genes. (A) McrA sequences from borehole 275 U1301B are in bold magenta type face. Close relatives based on microarray analyses 276 of JdF Ridge hydrothermal vent chimneys and seafloor basalt are in green (18) and

277 cyan (19), respectively. (B) DsrB sequences from borehole U1301B are in bold 278 magenta type face, and sequences from subseafloor sediment off Peru in cyan (22).

279 Bootstrap support (in \%, 1,000 replications) is indicated at each branching point.

281 Figure 2. Macro-and micro-scale distribution of S-isotopic data. On the left, $\delta^{34} \mathrm{~S}$ -

282 depth profile of pyrite granules, analyzed by laser ablation and secondary ion mass

283 spectrometry (SIMS), and bulk S pools (AVS, CRS). On the right, thin section 284 micrograph showing individual pyrite granules and their $\delta^{34} \mathrm{~S}$. The dashed magenta 285 line indicates the sampling depth of the thin section. The dashed black lines mark the 286 intermediate depth interval. Pyrite grains with a sufficient diameter for $\delta^{34} \mathrm{~S}$ 287 determination $(10 \mu \mathrm{m})$ were limited to this interval. The scale bar is $200 \mu \mathrm{m}$.

289 Figure 3. Depth-related trends in (A) TOC content, (B) $\delta^{13} \mathrm{C}-\mathrm{TOC}$, and $(\mathrm{C}) \delta^{13} \mathrm{C}$ 290 carbonate. Cores with functional gene detection are indicated in A and B. Dashed 291 vertical lines indicate $\delta^{13} \mathrm{C}$-DOC (B) and $\delta^{13} \mathrm{C}-\mathrm{DIC}(\mathrm{C})$ values from $1026 \mathrm{~B}$ and BBS. 292 Because the carbonate content of rock samples used in (A) and (B) was too low for 293 analyses, $\delta^{13} \mathrm{C}$ from carbonate veins are shown in (C). The reduced intermediate depth 294 interval falls between the dashed horizontal lines. $\mathrm{All} \delta^{13} \mathrm{C}$ are in \%o vs. VPDB. 
95 JdFMG-mcrA, GU182109 (46)

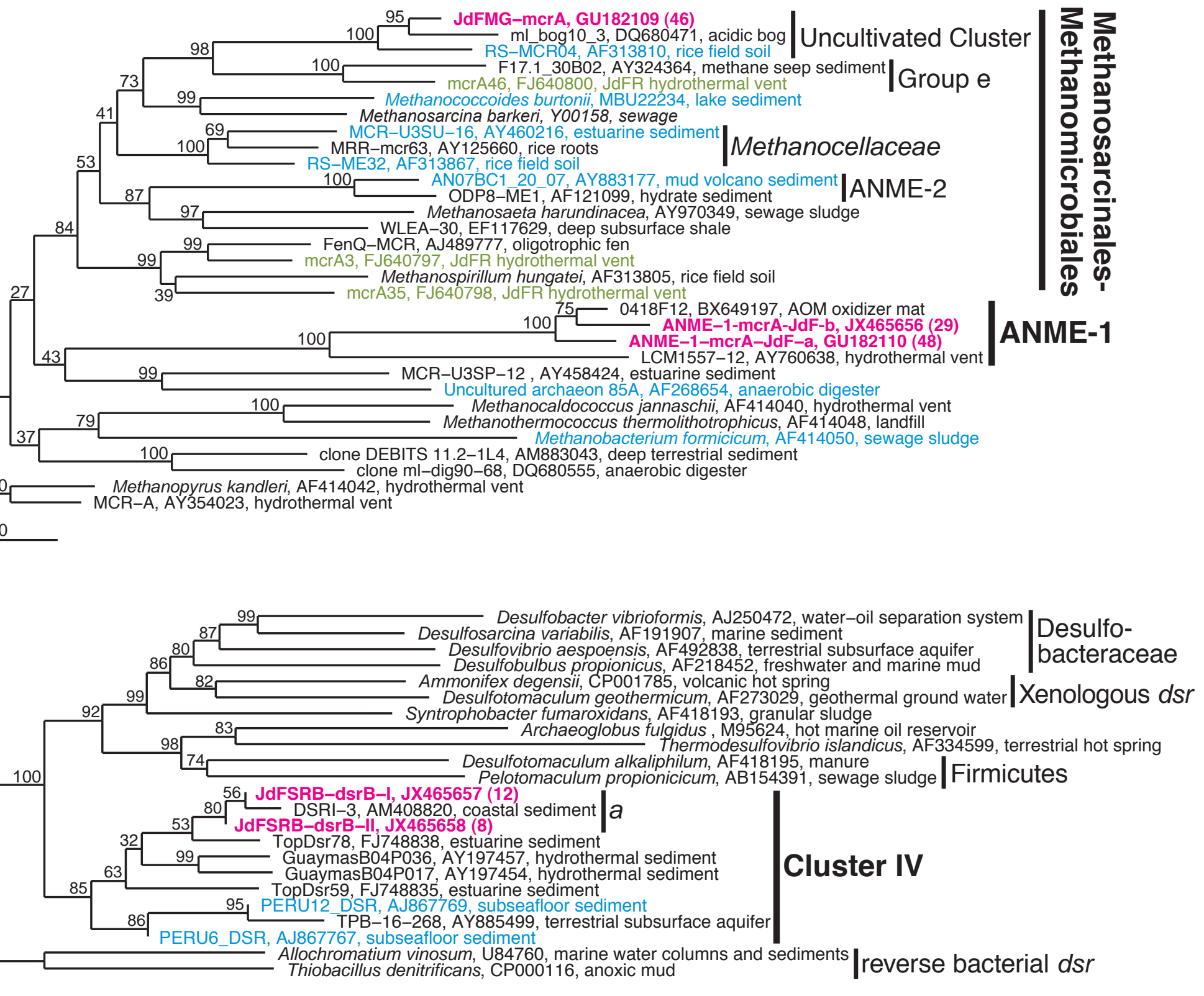




\section{$\delta^{34} S(\% \circ)$}

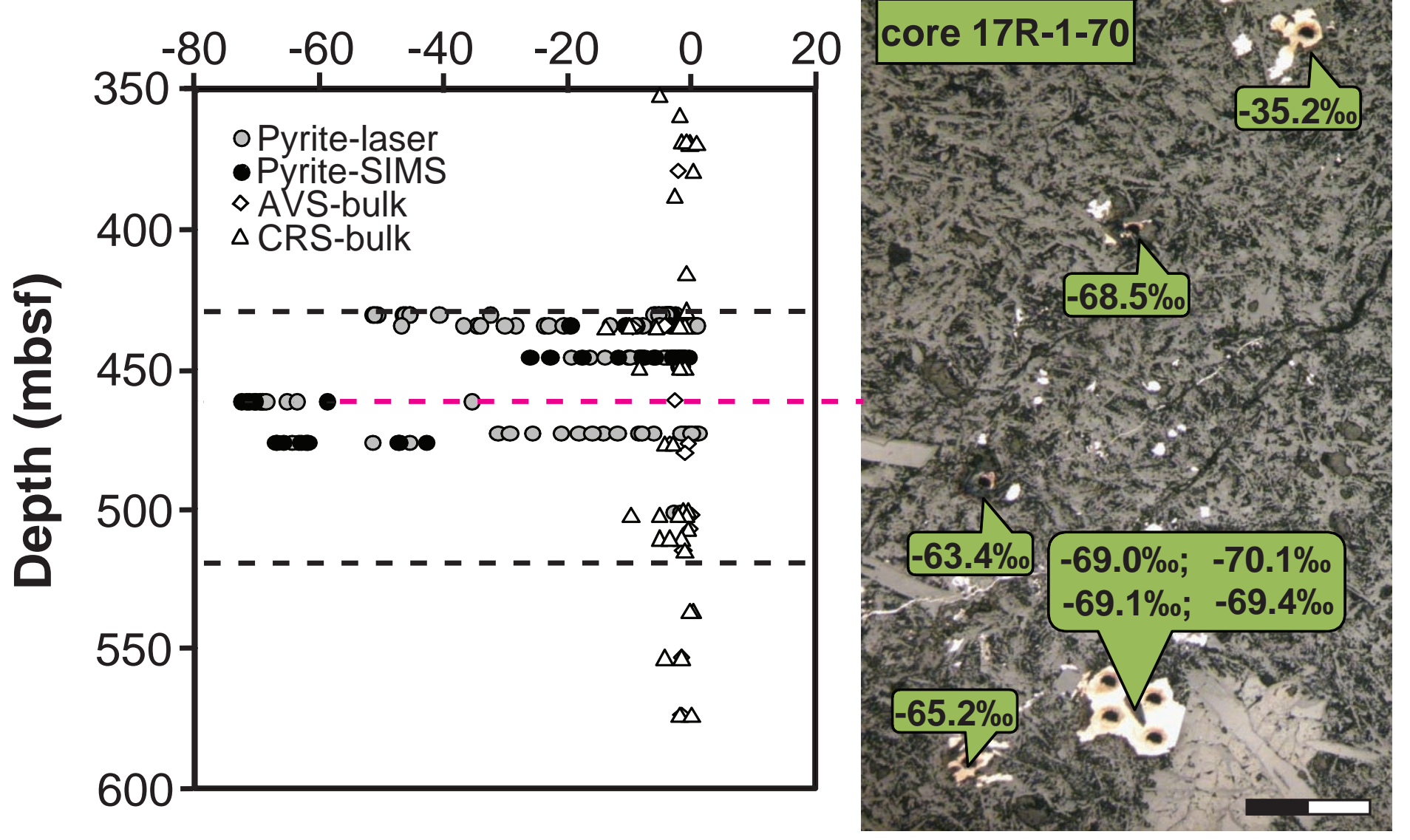




\section{TOC (wt\%) \\ $\delta^{13} \mathrm{C}-\mathrm{TOC}(\%)$ \\ $\delta^{13} \mathrm{C}$-carbonate (\%o)}

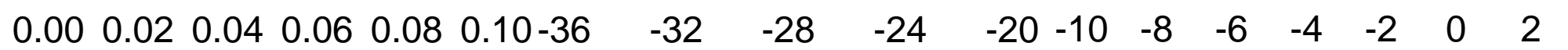

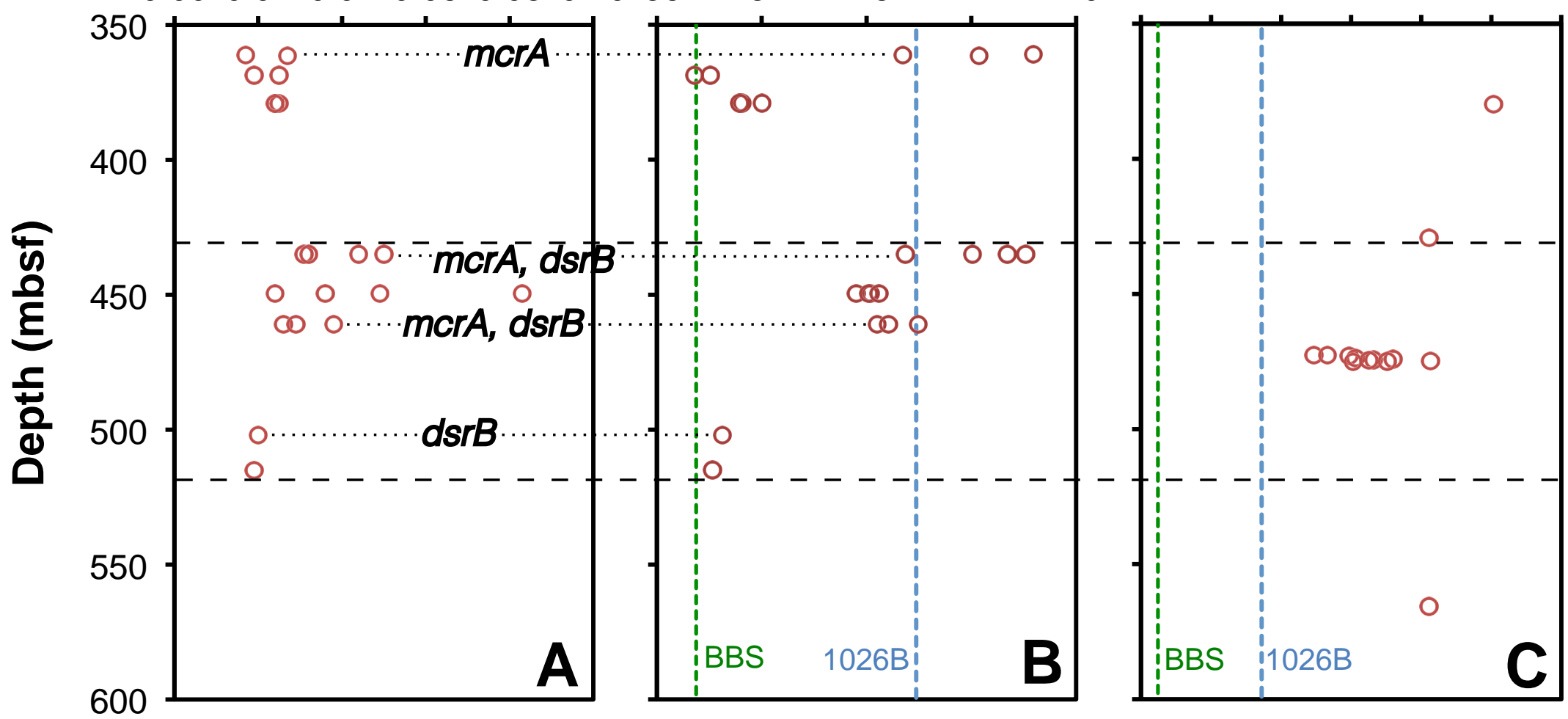




\section{Supplementary Materials}

\section{Materials and Methods}

Sample collection. Basalt cores from borehole U1301B were sampled using a Rotary Core Barrel (RCB) (9). Freshly recovered, intact whole-round basalt cores were decontaminated, cracked aseptically, and subsampled to measure drilling fluid contamination (31). For DNA extractions, only rock samples were used in which drilling fluid contamination was minimal $\left(<2\right.$ contaminant cells $\mathrm{g}^{-1}$ basalt $)(31)$. This limited analyses to rocks with small, smectite-dominated cross-cutting veins, which - unlike carbonate-dominated major veins - remained intact during drilling, and could be cracked open and aseptically sampled shipboard after core recovery. All processed samples were stored at $-80^{\circ} \mathrm{C}$ prior to extraction of DNA in the home laboratory.

DNA Extraction. Using sterile spatulas, 2-4 $\mathrm{cm}^{2}(0.3-0.5 \mathrm{~g})$ of inner vein surfaces were scraped off and DNA extracted following the same protocol as previously for RNA (32) except that the sodium phosphate $\left(\mathrm{NaH}_{2} \mathrm{PO}_{4}\right)$ concentration of the extraction buffer was raised to $120 \mu \mathrm{M}$, the $\mathrm{pH}$ of the extraction buffer and phenol increased to 8.0, and bead-beating reduced to $15 \mathrm{~s}$ at a speed of 4.0. Negative controls containing no basalt samples were run in parallel to check for contamination of extraction reagents. Samples and controls were purified with the PowerClean DNA Clean-Up Kit (MOBIO laboratories, Carlsbad, CA).

Primer Selection and PCR Amplification. mcrA was PCR-amplified using the mcrIRD and ANME-1-mcrI primer pairs. These primer pairs target all known and several novel $m c r A$ gene clusters when used complementarily, as shown in extensive tests with marine sediment samples (33). $d s r B$ was PCR-amplified by nested PCR with published external primers (DSR1F/4R) (14), and a newly designed primer mixture used internally (dsrB F1a-h/4RSIla-f), after tests with published primers had produced negative results (Tables S12 and S13). The PCR protocol consisted of (1) $1 \times 2$ min denaturation $\left(98^{\circ} \mathrm{C}\right)$, (2) $40 \times$ (a) $30 \mathrm{~s}$ denaturation $\left(95^{\circ} \mathrm{C}\right)$, (b) $30 \mathrm{~s}$ annealing (mcrIRD: $55^{\circ} \mathrm{C}$; ANME-1-mcrI: $63^{\circ} \mathrm{C}$; DSR1F/4R: $54^{\circ} \mathrm{C}$, dsrB F1a-h/4RSI1a-f: $\left.56^{\circ} \mathrm{C}\right)$, (c) 1 min extension $\left(72^{\circ} \mathrm{C}\right)$, and (3) $1 \times 5$ min extension $\left(72^{\circ} \mathrm{C}\right)$. In each PCR assay, negative controls for contamination of extraction and PCR reagents were run and found to be negative.

Cloning, sequencing, and phylogenetic analyses. PCR fragments were purified in a 2\% low-melting point agarose gel and agarose removed with a S.N.A.P. MiniPrep Kit. Purified DNA was cloned and inserted into electrocompetent $E$. coli using the TOPO TA Kit (both kits by Invitrogen, Carlsbad, USA). All trees were constructed with nucleotides in ARB Neighbour Joining using Jukes-Cantor correction (34).

Nucleotide sequence accession numbers. The GenBank nucleotide accession numbers are GU182109-GU182110, and JX465656-JX465658.

Solid-phase $\mathbf{S}$ Analyses. Contents and $\delta^{34} \mathrm{~S}$-compositions of bulk S pools (AVS, $\left.\mathrm{CRS}, \mathrm{SO}_{4}-\mathrm{S}\right)$ were analyzed on rock powders using published protocols $(5,23)$.

The $\delta^{34} \mathrm{~S}$ of pyrite grains was measured on polished rock thin-sections by SIMS using the mono-collection Cameca IMS 1280 (35), and by LA-MC-ICPMS (Laser 
Ablation Multiple Collector Inductively Coupled Plasma Mass Spectrometry) using the NewWave UP213 laser coupled to the Neptune (Thermo) MC-ICP-MS (36). For both techniques, the minimum grain diameter for $\delta^{34} \mathrm{~S}$-determination was $10 \mu \mathrm{m}$. In certain samples (e.g. 14R-1, 17R-1, 19R-1), pyrite grains were measured with SIMS and LAMC-ICPMS and showed agreement within analytical uncertainties. Details of both techniques are outlined in the following paragraphs.

For the SIMS technique, a beam of ${ }^{133} \mathrm{Cs}^{+}$ions was used for sputter-ionizing $\mathrm{S}$ as negatively charged secondary ions from pyrite grains. A mass resolving power (MRP) of $\sim 5000$ was used with a primary $\mathrm{Cs}^{+}$beam current switched to a spot of $\sim 2 \mathrm{~mm}$ diameter with a current of $\sim 6 \mathrm{pA}$. Peak calibration and pre-sputtering was made for each spot analysis and the intensity data was then processed by an off-line time-interpolation correction protocol to minimize the effect of variations of the primary beam intensity on measured isotope ratios. Pyrite standards used were: Ruttan (+1.2 \%o VCDT), MVE0414-4 (-13.15\%o), and Balmat (+15.1\%o). For each session, at least two of each were measured repeatedly to ascertain that the instrumental mass fractionation factor $(a)$ was statistically identical for all standards. $a$ varied from session to session and day to day, but was constant during a day. No efforts were made to modify instrument optical parameters on a day-to-day basis to control $a$.

The LA-MC-ICPMS technique followed a published method (36), in which singlespot analyses were made using a $30 \mu \mathrm{m}$ diameter beam size with an energy density of $\sim 9-10 \mathrm{~J} \mathrm{~cm}^{-2}$. Standard-sample bracketing was used to correct for the instrumental mass bias of unknown pyrite samples using standard-solutions calibrated against in-house pyrite standards of known composition (GAV-18=10.4\%; ALV-4053=2.5\%o).

Solid-phase C Analyses. TOC content was determined by element analyzer (EA). Traces of carbonate $\mathrm{C}$ were removed by reaction with dilute $(3 \mathrm{~N}) \mathrm{HCl}$, followed by washing in distilled $\mathrm{H}_{2} \mathrm{O}(37)$. $\delta^{13} \mathrm{C}$-TOC was determined with a Costech EA coupled to a Thermo Scientific Delta V plus isotope ratio MS (IRMS), using IAEA 600 Caffeine $\left(\delta^{13} \mathrm{C}\right.$ $=-27.77 \%$ VPDB) and IAEA-CH-6 Sucrose (-10.45\%o) as calibration standards. Rock powders were degassed at $100^{\circ} \mathrm{C}$ and stored under vacuum to minimize adsorption of atmospheric $\mathrm{CO}_{2}$. Replicate analyses of low-C content samples $(<500 \mathrm{ppm})$ were within \pm 70 ppm and $\pm 0.5 \%$ o $\delta^{13} \mathrm{C}$. C blanks are less than $6 \%$ of reported $\mathrm{C}$ contents. $\delta^{13} \mathrm{C}$ carbonate was analyzed as described previously (10). Since the carbonate content of rocks used for bulk geochemical analyses and smectite-dominated veins used for genetic analyses was too low for $\delta^{13} \mathrm{C}$-analyses, carbonate-dominated major veins were used.

Basalt enrichments. Methanogen Medium 141 (Deutsche Sammlung von Mikroorganismen und Zellkulturen) was prepared with minor modifications (Table S8). The initial inoculum consisted of fresh basalt shards from rock interiors in which drilling fluid contamination was near or below the detection limit $\left(<0.1\right.$ contaminant cells $\mathrm{g}^{-1}$ basalt; 1R-1-79, 14R-1-11, 23R-2-21) (31). For transfers, a few incubated basalt pieces were added to fresh medium containing triple-autoclaved basalt pieces and no sulfate. Headspace methane and dissolved species (sulfate, sulfide, DIC) were measured via standard protocols. $\delta^{13} \mathrm{C}$-methane was determined using a Trace GC coupled via GC combustion III interface to a Delta plus XP plus IRMS (all Thermo Finnigan) following a previously published protocol (38). The absence of color changes due to oxidation of resazurin indicated that media remained fully anoxic throughout incubations. 

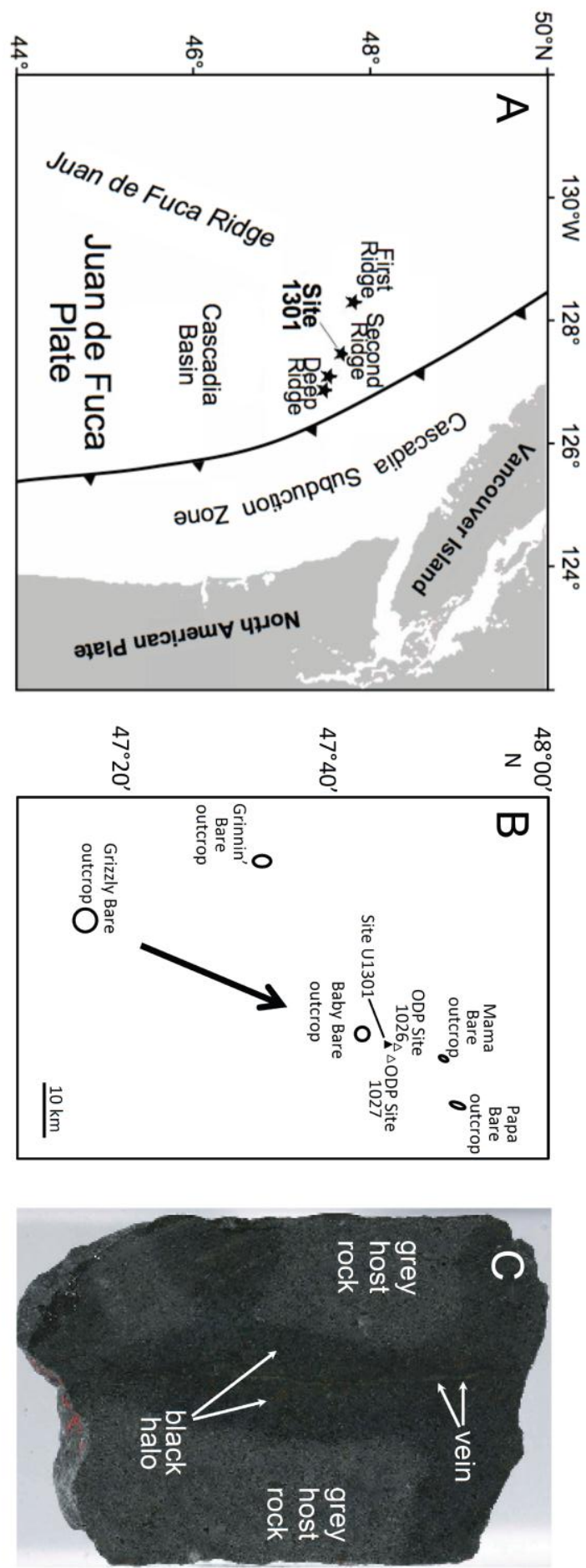

Fig. S1. (A) Map of study area. (B) General direction of subsurface flow from Grizzly Bare outcrop to the Baby Bare Spring area and U1301 $(6,11)$. (C) Cross section through basalt core from U1301B, showing the alteration halos that surround basalt veins or fractures (adapted from (9)). 


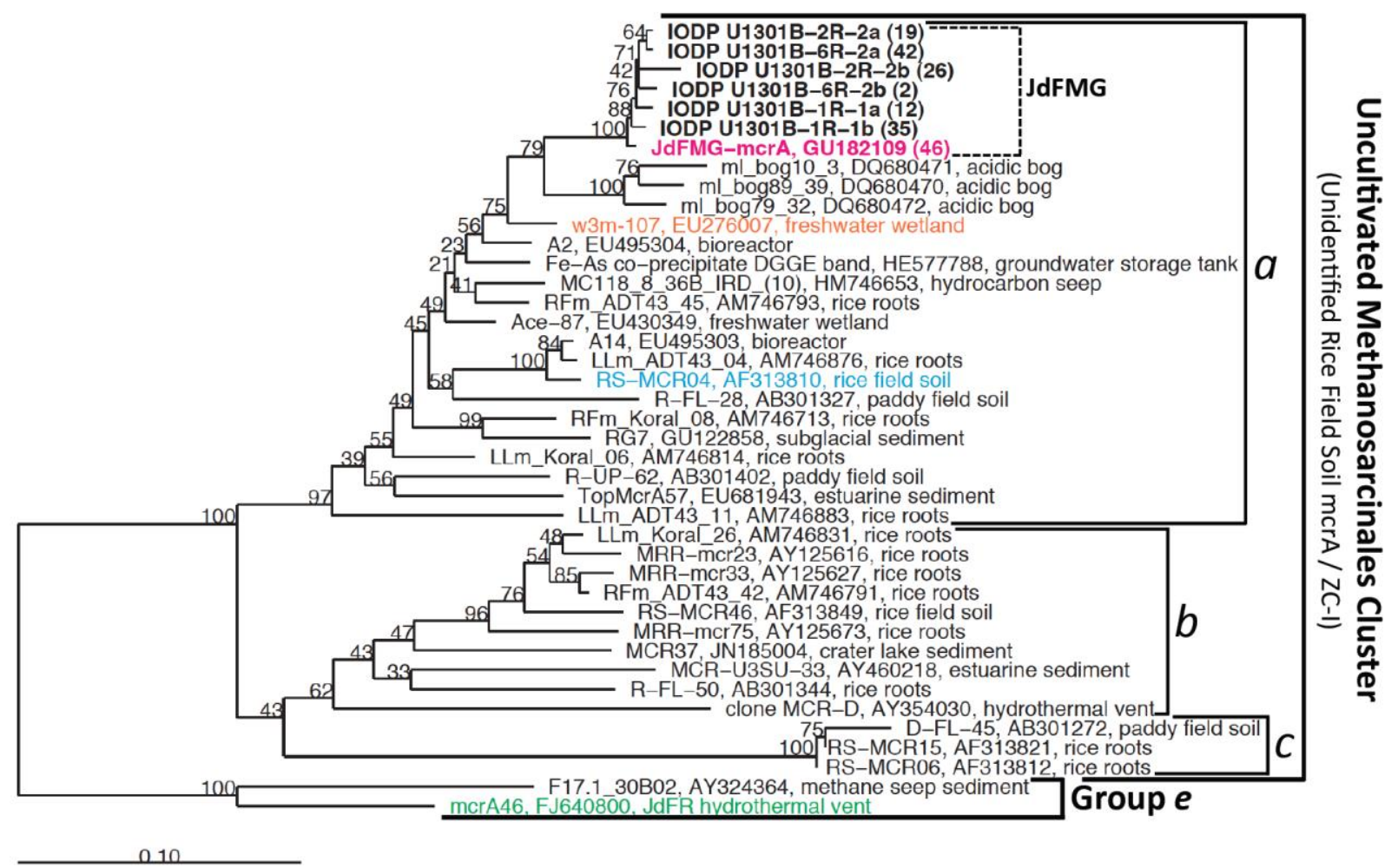

Fig. S2. Phylogenetic tree of the Uncultivated Methanosarcinales Cluster (congruent with the Unidentified Rice Field Soil mcrA (15) and Zoige cluster I (ZC-I); 16) based on mcrA sequences. The uncultivated Methanosarcinales group $e$ is used as an outgroup. All phylotypes detected in this study in bold type face, with the one displayed in Fig. 1a in magenta. Clone numbers sequenced for each phylotype are shown in parentheses. The closely related methanogenic phylotype that was enriched in wetland sediment is in orange (16), the closest relative of an $m c r A$ gene detected in Juan de Fuca Ridge seafloor basalt by microarray analysis is in blue (18), and the closest relative from Juan de Fuca Ridge hydrothermal vent chimneys in green (17). Constructed from nucleotides in ARB Neighbour Joining using Jukes-Cantor correction. Bootstrap support (in \%, 1,000 replications) is indicated at each branching point. 


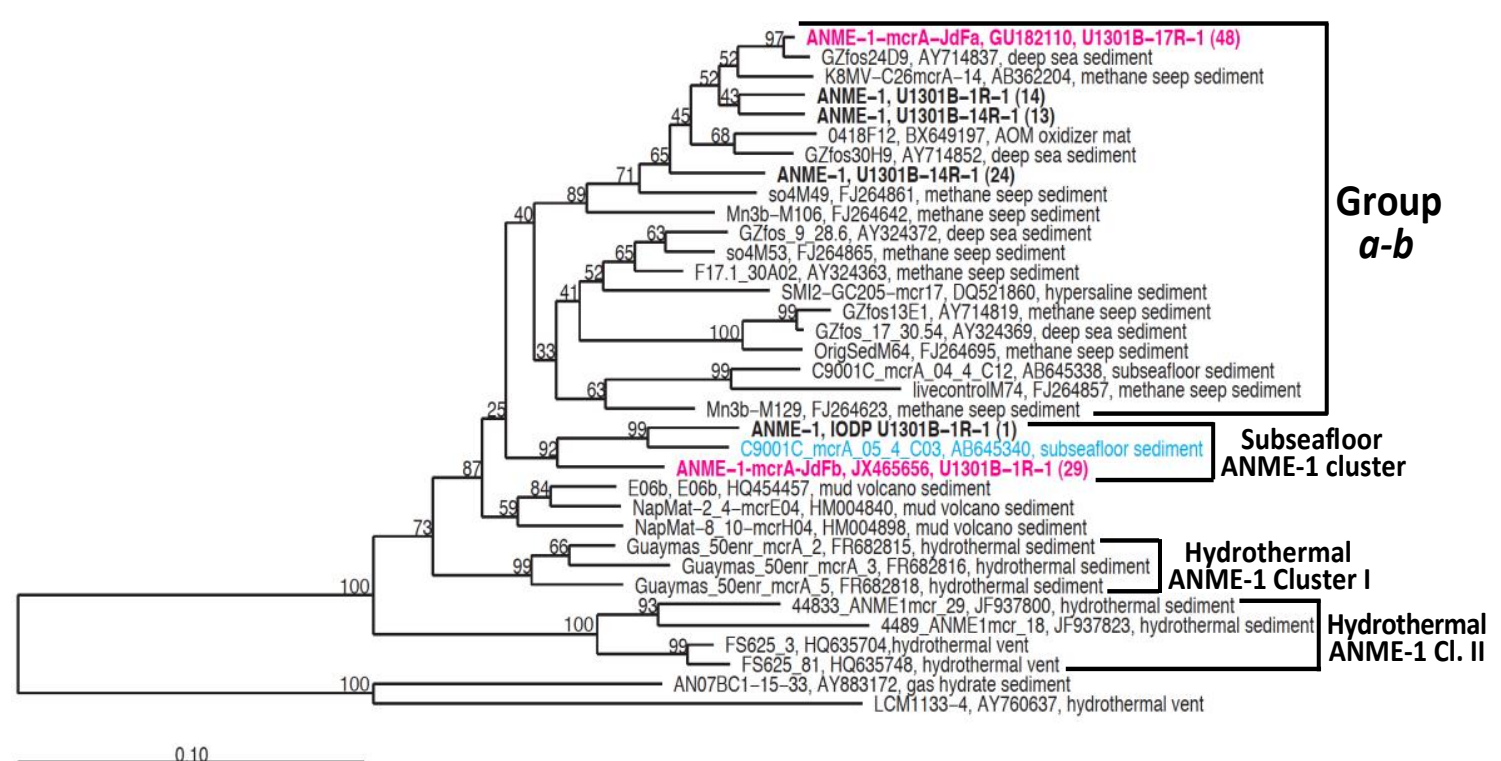

Fig. S3. Phylogenetic tree of ANME-1 based on mcrA sequences. All phylotypes from subseafloor basalt of the Juan de Fuca Ridge Flank appear in bold type face, with ones included in Fig. 1A in magenta. Clone numbers sequenced for each phylotype are shown in parentheses. In cyan, the only other deep subseafloor ANME-1 sequence in Genbank, from sediments of the Northwest Pacific off Shimokita Peninsula (Nunoura et al., unpubl.). Highly divergent ANME-1 sequences from the Lost City Hydrothermal Field (LCM1133-4) and gas hydrate sediment (AN07BC1-15-33), which form a distinct cluster of their own, are used as an outgroup. Constructed with nucleotides in ARB Neighbour Joining using Jukes-Cantor correction. Bootstrap support (in \%, 1,000 replications) is indicated at each branching point. 


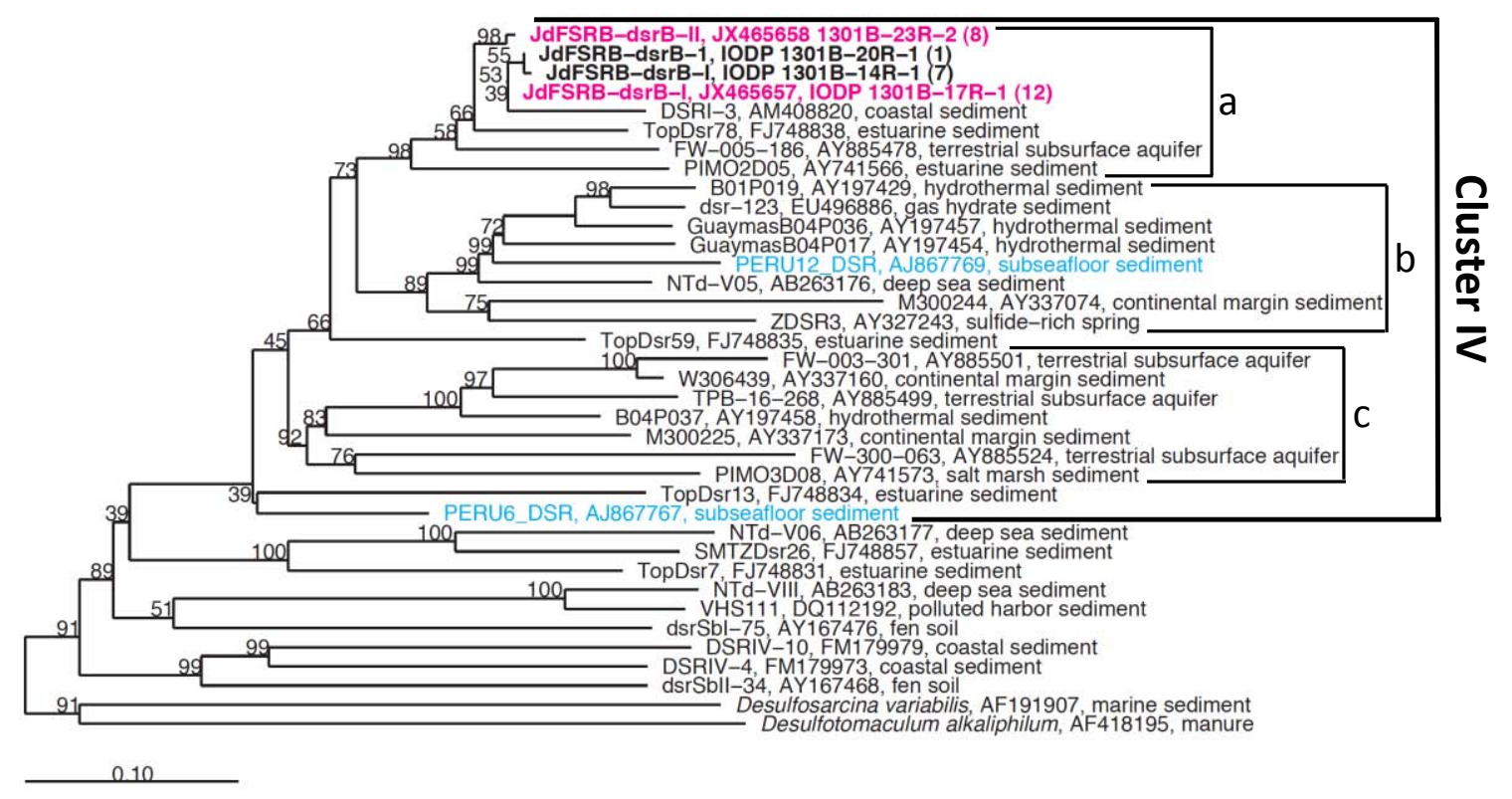

Fig. S4. Phylogenetic tree of Cluster IV and related $d s r B$ clusters. Phylotypes from Juan de Fuca Ridge Flank basalt appear in bold type face, with ones shown in Fig. 1B in magenta. Clone numbers sequenced for each phylotype are shown in parentheses. Sequences detected in subsurface sediment of the Peru Margin are shown in blue $(S 20)$. Cluster IV falls into at least 3 distinct subclusters $(a-c)$ that each have high bootstrap support $(>85 \%)$. All JdFSRG fall into subcluster $a$. Constructed with nucleotides in ARB Neighbour Joining using Jukes-Cantor correction. Sequences of Desulfobacteraceae (Desulfosarcina variabilis) and Firmicutes (Desulfotomaculum alkaliphilum) used as outgroups. Bootstrap support (in \%, 1,000 replicates) shown at each branching point. 


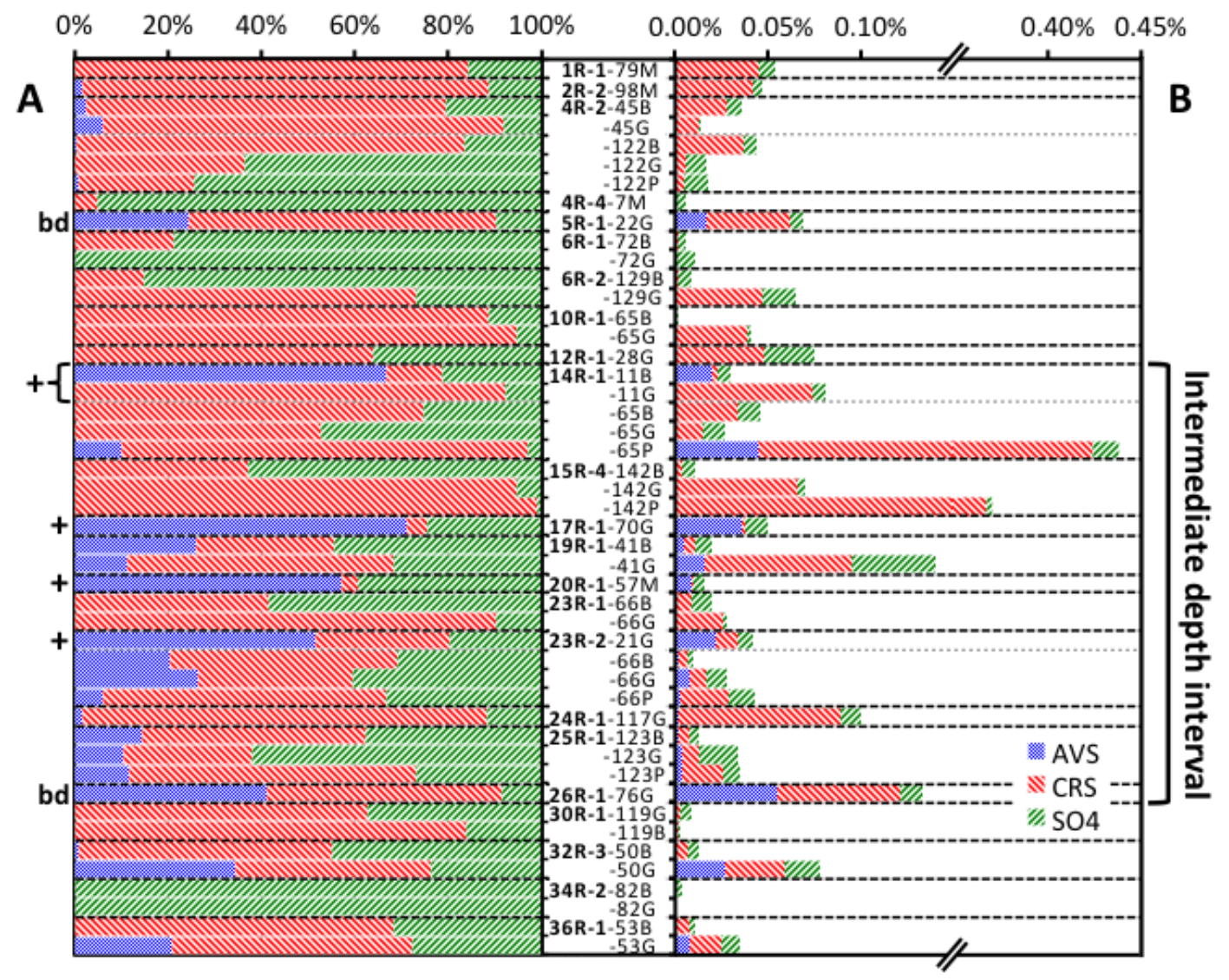

Figure S5. (A) Relative weight contributions of AVS, CRS, and $\mathrm{SO}_{4}-\mathrm{S}$ to total S; (B) Cumulative weight contributions of AVS, CRS, and $\mathrm{SO}_{4}-\mathrm{S}$ to total basalt sample. Sample IDs are shown in the middle. Rock samples in which DNA extracts were tested for $d s r B$ presence are indicated on the far left. All data is listed in Table S2. B = black alteration halo; $\mathrm{G}=$ grey host rock; $\mathrm{P}=$ pyrite front' a narrow zone (typically $<0.1 \mathrm{~mm}$ ) of concentrated disseminated pyrite along the boundary between an alteration halo and the adjacent host rock, located at interface of black alteration halo and grey host rock; $\mathrm{M}=$ mixed lithology. 


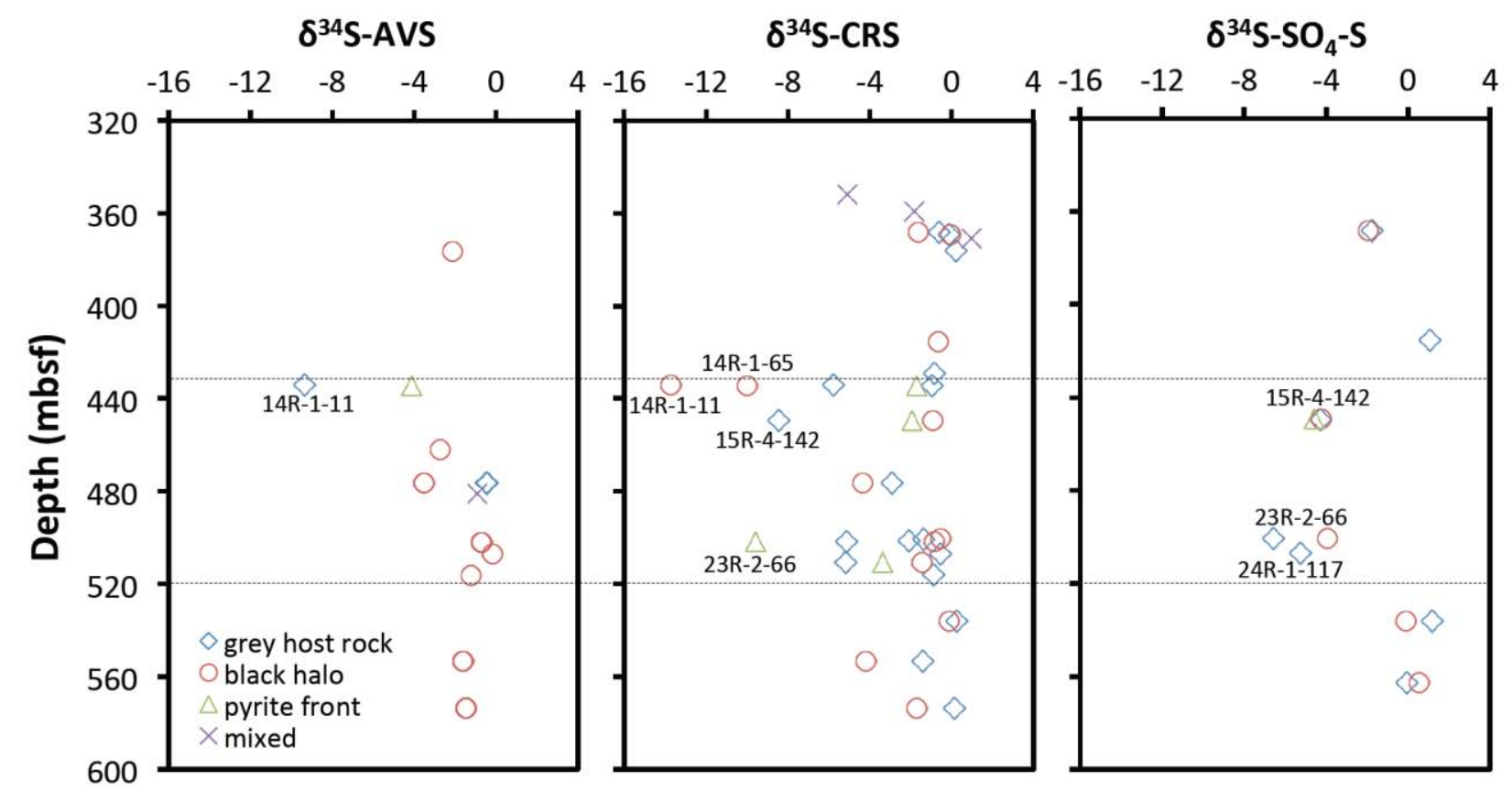

Fig. S6. Depth-related trends in $\delta^{34} \mathrm{~S}$ of CRS, AVS, and $\mathrm{SO}_{4}-\mathrm{S}$ at IODP Site U1301. The more reduced intermediate depth interval falls between the dashed lines. All $\delta^{34} \mathrm{~S}$-values are expressed in \%o vs. VCDT. 


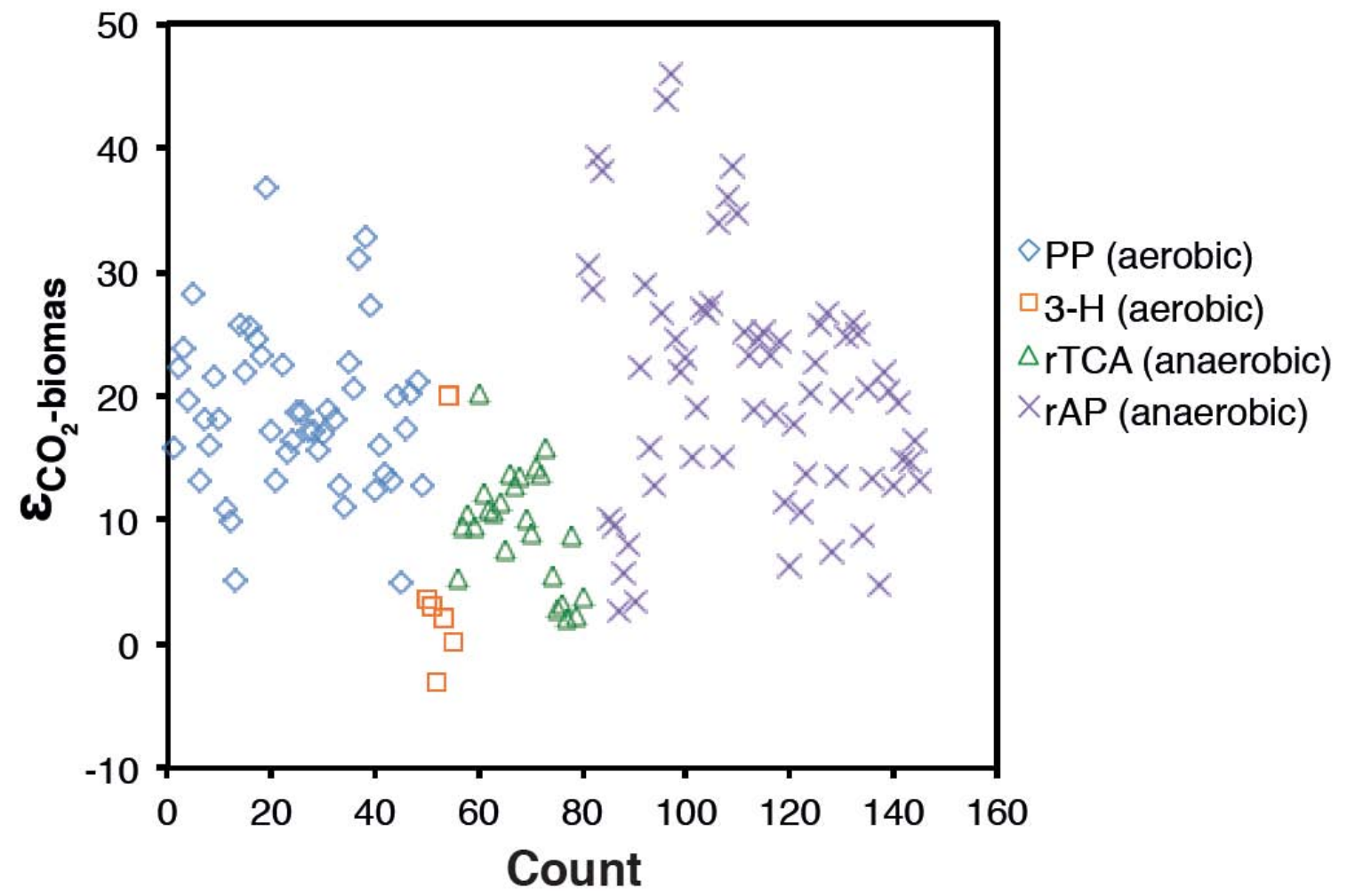

Fig. S7. Compiled data from Table $\mathrm{S} 6$ on $\delta^{13} \mathrm{C}$-fractionations associated with aerobic and anaerobic $\mathrm{C}$-fixation pathways. Abbreviations: $\mathrm{PP}=$ pentose phosphate (Calvin-BensonBassham) cycle, $3-\mathrm{H}=3$-hydroxypropionate cycle, $\mathrm{rTCA}=$ reverse tricarboxylic acid cycle, $\mathrm{rAP}=$ reductive acetyl CoA pathway. Note that the PP pathway also occurs in some anoxygenic phototrophs (Chromatium, Thiocapsa, Rhodospirillum; Table S6). 


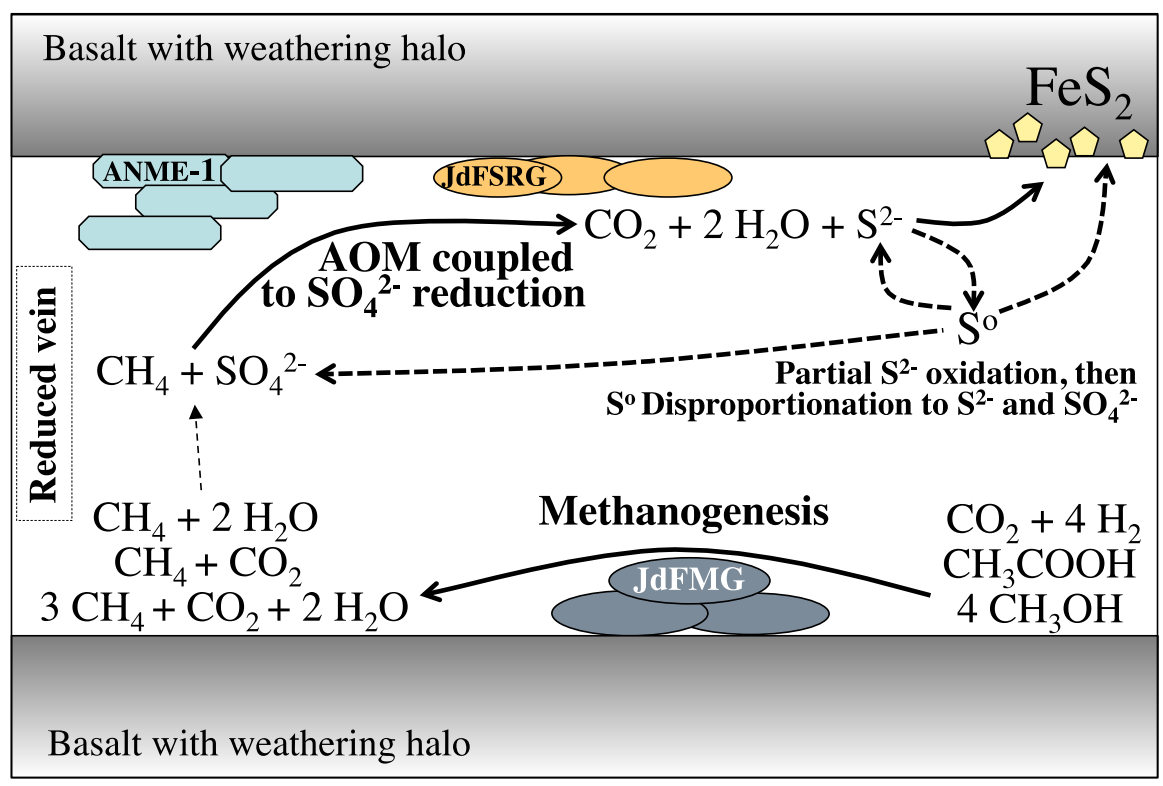

Fig. S8. Concept sketch of microbial methane and S-cycling in reduced veins of Juan de Fuca subsurface basalt (e.g. core 17R-1-70). Potential methanogenic substrates include $\mathrm{H}_{2} / \mathrm{CO}_{2}$, acetate, and methylated organic substrates. Methanogens, methanotrophs and sulfate reducers may coexist (as shown) or inhabit separate chemical microenvironments. 


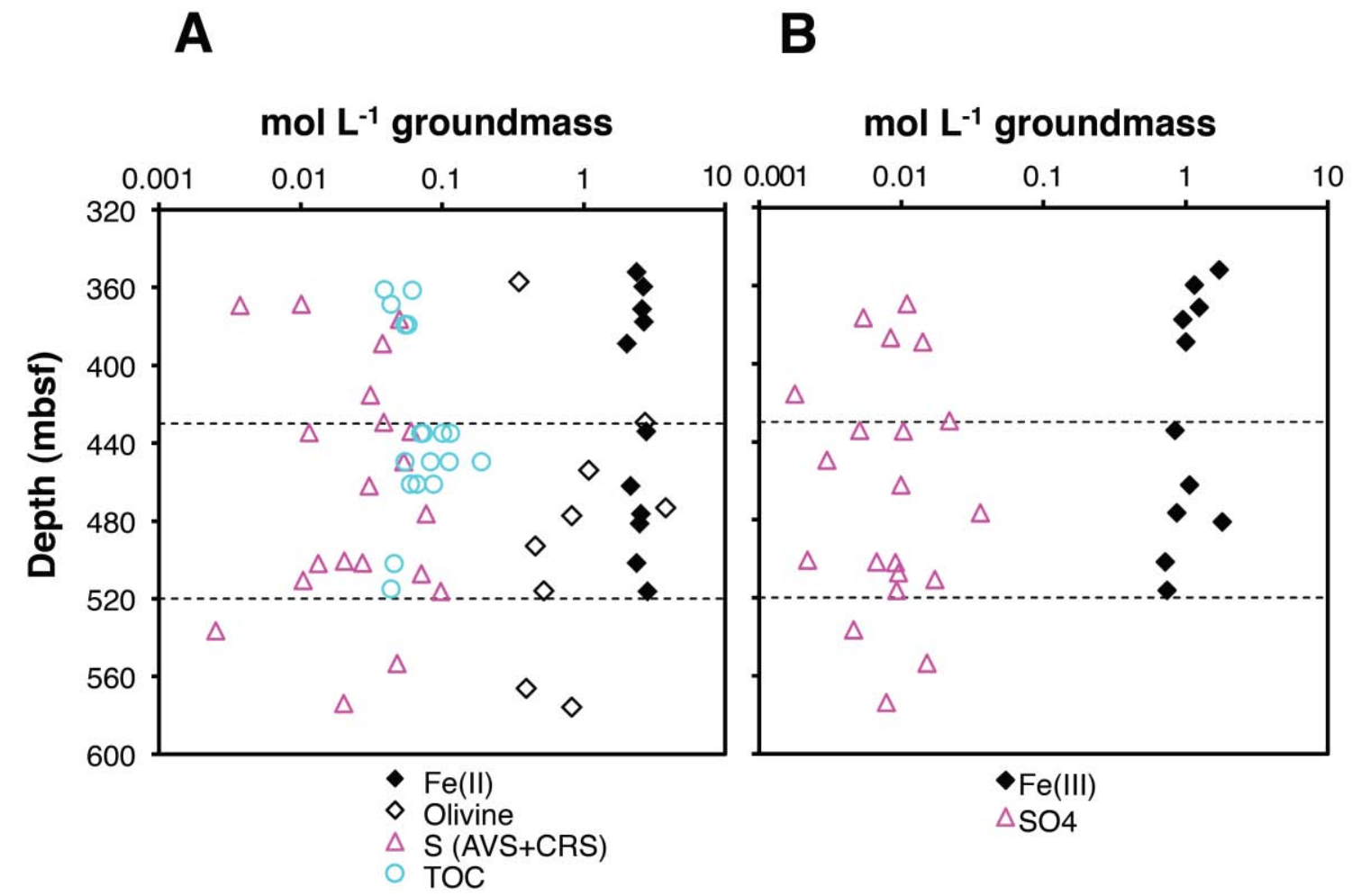

Fig. S9. (A) Molar contents of the potential electron donors Fe(II), reduced S (includes both AVS- and CRS-S), and TOC per liter of basalt groundmass in borehole U1301B. Values for $\mathrm{Fe}(\mathrm{II})$ in olivine $\left((\mathrm{Mg}, \mathrm{Fe})_{2} \mathrm{SiO}_{4}\right)$ are also shown. (B) Molar contents of the potential electron acceptors $\mathrm{Fe}(\mathrm{III})$ and $\mathrm{SO}_{4}$ per liter of groundmass at U1301B. The more reduced intermediate depth interval falls between the dashed lines. Except for olivine, which was obtained from Fisher et al. $(2005 ; 9)$, all data from this study. See Table S10 for a listing of potential energy-yielding reactions in borehole U1301B. 
Table S1. Sample identity, depth, lithology, total S and TOC content in host rock and halos ( $\mathrm{n}=\mathrm{sample}$ size), Fe(II) fraction of total Fe $(\mathrm{FeT}), \delta^{34} \mathrm{~S}$-pyrite, $\delta^{34} \mathrm{~S}-\mathrm{CRS}$ and -AVS of host rock ${ }^{1}$ and halos ${ }^{1}$ (halos in parentheses), $\delta^{13} \mathrm{C}-\mathrm{TOC}, m c r A$ and $d s r B$ clone library composition with number of clones obtained for each phylotype in parentheses. [wt $\%=\%$ of sample weight, bd $=$ below detection; nd $=$ not determined; $\delta^{13} \mathrm{C}$-values in \%o vs. Vienna Pee Dee Belemnite (VPDB), $\delta^{34} \mathrm{~S}$ in \%o vs. Vienna-Canyon Diablo Troilite (VCDT).]

${ }^{1}$ host rock = main basalt type; exhibits a pervasive dark gray background alteration manifest by secondary saponite; halo $=$ distinctly colored band of rock (typically 1 $15 \mathrm{~mm}$ wide) flanking a vein; color imparted by differing secondary minerals (black halos contain celadonite, brown halos contain iron oxy-hydroxide).

\begin{tabular}{|c|c|c|c|c|c|c|c|c|c|c|c|}
\hline \multirow{2}{*}{$\begin{array}{l}\text { Sample } \\
\text { ID }^{2}\end{array}$} & \multirow{2}{*}{$\begin{array}{l}\text { Depth } \\
\text { (mbsf) }\end{array}$} & \multirow[t]{2}{*}{ Lithology $^{3}$} & \multirow{2}{*}{$\begin{array}{l}\text { Total S } \\
(\mathrm{wt} \%)^{4}\end{array}$} & \multirow[t]{2}{*}{ TOC (wt $\%)$} & \multirow[t]{2}{*}{$\mathrm{Fe}^{3+} / \mathrm{FeT}^{5}$} & \multicolumn{3}{|l|}{$\delta^{34} \mathrm{~S}(\% 0)$} & \multirow{2}{*}{$\begin{array}{l}\delta^{13} \mathrm{C}-\mathrm{TOC} \\
(\% \mathrm{o})\end{array}$} & \multirow{2}{*}{$\begin{array}{l}\text { mcrA cluster } \\
\text { (\# of clones) }\end{array}$} & \multirow{2}{*}{$\begin{array}{l}d s r B \text { cluster } \\
(\# \text { of clones })\end{array}$} \\
\hline & & & & & & pyrite (\%) & CRS (\%o) & $\operatorname{AVS}(\%)^{6}$ & & & \\
\hline 1R-1-79 & 352.0 & $\begin{array}{l}20 \% \text { breccia and pillow basalt ( } 30 \% \text { black } \\
\text { halo) with small disseminated sulfide grains }\end{array}$ & 0.04 & nd & 0.42 & bd & -5.1 & nd & nd & $\begin{array}{l}\text { JdFMG (47), } \\
\text { ANME-1 (44) }\end{array}$ & nd \\
\hline 2R-2-98 & 359.6 & pillow basalt, brown/black halos $(80 \%)$ & 0.06 & $\begin{array}{c}0.017-0.027 \\
(\mathrm{n}=3)^{6}\end{array}$ & 0.30 & bd & -1.8 & nd & $\begin{array}{l}-21.6 \text { to }-26.6 \\
(\mathrm{n}=3)^{7}\end{array}$ & JdFMG (45) & nd \\
\hline $4 \mathrm{R}-4-7$ & 371.2 & pillow basalt, brown halo (Fe oxides) & 0.05 & $\begin{array}{c}0.019 \\
\text { (halo } 0.025)^{6}\end{array}$ & 0.32 & bd & 1 & nd & $\begin{array}{l}-34.6 \text { (halo - } \\
34.0)^{7}\end{array}$ & $\mathrm{bd}$ & nd \\
\hline $5 \mathrm{R}-1-22$ & 377.5 & pillow basalt, close to pillow rim & 0.09 & $\begin{array}{c}0.024-0.025 \\
(\mathrm{n}=4)^{6}\end{array}$ & 0.26 & bd & 0.2 & -2.1 & $\begin{array}{c}-32.0 \text { to }-32.8 \\
(\mathrm{n}=4)^{7}\end{array}$ & $\mathrm{bd}$ & $\mathrm{bd}$ \\
\hline $6 \mathrm{R}-2-129$ & 388.8 & pillow basalt with black halo & $\begin{array}{c}0.07 \\
\text { (halo } 0.03 \text { ) }\end{array}$ & nd & $\begin{array}{c}0.33 \\
\text { (halo } 0.47 \text { ) }\end{array}$ & bd & -2.7 & nd & nd & JdFMG (44) & nd \\
\hline 14R-1-11 & 434.1 & $\begin{array}{l}\text { massive basalt with black halo (pyrite } \\
\text { disseminated in groundmass) }\end{array}$ & $\begin{array}{c}0.12 \\
\text { (halo } 0.10 \text { ) }\end{array}$ & $\begin{array}{c}0.031-0.050 \\
(\mathrm{n}=4)\end{array}$ & $\begin{array}{c}0.23 \\
\text { (halo } 0.38 \text { ) }\end{array}$ & -4 to -47 & $\begin{array}{l}-5.7 \\
(-13.7)\end{array}$ & $(-9.3)$ & $\begin{array}{c}-21.9 \text { to }-26.5 \\
(n=4)\end{array}$ & ANME-1 (37) & $\underset{(7)}{\text { Group IV }}$ \\
\hline $17 R-1-70$ & 462.1 & $\begin{array}{l}\text { pillow basalt with black halo, pyrite in } \\
\text { groundmass and along veins }\end{array}$ & $\begin{array}{c}0.10 \\
\text { (halo } 0.04 \text { ) }\end{array}$ & $\begin{array}{c}0.026-0.038 \\
(\mathrm{n}=3)\end{array}$ & $\begin{array}{c}0.33 \\
\text { (halo } 0.41 \text { ) }\end{array}$ & -35 to -72 & nd & -2.7 & $\begin{array}{l}-26.0 \text { to }-27.6 \\
(\mathrm{n}=3)\end{array}$ & $\begin{array}{l}\text { JdFMG (46), } \\
\text { ANME-1 (48) }\end{array}$ & $\begin{array}{l}\text { Group IV } \\
\text { (12) }\end{array}$ \\
\hline 20R-1-57 & 481.2 & $\begin{array}{l}\text { pillow basalt with oxidized groundmass (no } \\
\text { pyrite) }\end{array}$ & 0.03 & nd & 0.42 & bd & nd & -0.9 & nd & bd & $\begin{array}{l}\text { Group IV } \\
\text { (1) }\end{array}$ \\
\hline 23R-2-21 & 501.6 & $\begin{array}{l}\text { pillow basalt with black halo, only a single } \\
\text { pyrite crystal found; brown halo }\end{array}$ & $\begin{array}{c}0.05 \\
\text { (halo } 0.07 \text { ) }\end{array}$ & 0.020 & $\begin{array}{c}0.23 \\
\text { (halo } 0.24)\end{array}$ & -2 to -3 & -2.1 & $\begin{array}{c}0.0 \\
(0.0)\end{array}$ & -33.5 & bd & $\begin{array}{l}\text { Group IV } \\
(8)\end{array}$ \\
\hline 26R-1-76 & 516.3 & $\begin{array}{l}\text { pillow basalt with black halo, no pyrite } \\
\text { found }\end{array}$ & $\begin{array}{c}0.13 \\
\text { (halo 0.08) }\end{array}$ & 0.019 & $\begin{array}{c}0.21 \\
\text { (halo } 0.28 \text { ) }\end{array}$ & bd & -0.9 & -1.22 & -33.9 & bd & bd \\
\hline
\end{tabular}

${ }^{2}$ Sample designation as follows: 1R-1-79 = core 1, sampled by Rotary Core Barrel (R), section 1, $79 \mathrm{~cm}$ from section top

3 from $(9)$

${ }^{4}$ total $\mathrm{S}$ determined by elemental analyzer

${ }^{5} \mathrm{Fe}^{2+}$ determined by titration, total Fe (FeT) by Inductively Coupled Plasma Atomic Emission Spectroscopy (ICP-AES), Fe ${ }^{3+}$ calculated from difference.

${ }^{6}$ only samples with detectable CRS or AVS were analyzed.

${ }^{7}$ values from within the same core, but not from the same rock used for genetic analyses (also see Table S3). 
Table S2. Solid-phase S weight \% (wt \%) of basalt (wt \%), relative contributions of different $\mathrm{S}$ pools to total S (\%), and $\delta^{34} \mathrm{~S}$ of these same $\mathrm{S}$ pools. Bold font indicates samples also used for DNA extractions [ $\mathrm{bd}=$ below detection; - = not determined; $\delta^{34} \mathrm{~S}$ in $\%$ vs. VCDT.]

\begin{tabular}{|c|c|c|c|c|c|c|c|c|c|c|}
\hline & \multirow{2}{*}{$\begin{array}{l}\text { Depth } \\
\text { mbsf }\end{array}$} & \multicolumn{3}{|c|}{ S pools (wt \%) } & \multicolumn{3}{|c|}{$\%$ contributions } & \multicolumn{3}{|c|}{$\delta^{34} S$} \\
\hline & & AVS CR & $\mathrm{SO}_{4}$ & Total & & & $\mathrm{O}_{4}-\mathrm{S}$ & AVS & CRS & $\mathrm{SO}_{4}-\mathrm{S}$ \\
\hline 1R-1-79M & 352.0 & $\begin{array}{lll}0.00 & 0.05\end{array}$ & 0.01 & 0.05 & 0 & 84 & 16 & bd & -5.1 & - \\
\hline 2R-2-98M & 359.6 & $\begin{array}{lll}0.00 & 0.04\end{array}$ & 0.01 & 0.05 & 2 & 87 & 12 & bd & -1.8 & - \\
\hline $4 R 2-45 B$ & 368.5 & $0.00 \quad 0.03$ & 0.01 & 0.04 & 2 & 77 & 21 & bd & -1.6 & -1.9 \\
\hline $4 \mathrm{R} 2-45 \mathrm{G}$ & 58.5 & $0.00 \quad 0.01$ & 0.00 & 0.01 & 6 & 86 & 8 & bd & -0.6 & -1.7 \\
\hline $4 R-2-122 B$ & 369.3 & $0.00 \quad 0.04$ & 0.01 & 0.04 & 1 & 83 & 17 & bd & -0.1 & - \\
\hline $4 \mathrm{R}-2$ & 369.3 & 0.000 .01 & 0.01 & 0.02 & 0 & 37 & 63 & bd & -0.1 & - \\
\hline $4 \mathrm{R}-2-122 \mathrm{P}$ & 369.3 & 0.000 .00 & 0.01 & 0.02 & 1 & 25 & 74 & bd & bd & - \\
\hline 4R-4-7M & 371.2 & $\begin{array}{lll}0.00 & 0.00\end{array}$ & 0.01 & 0.01 & 0 & 5 & 95 & bd & 1.0 & - \\
\hline $5 R-1-22 G$ & 376.5 & $\begin{array}{ll}0.02 & 0.05\end{array}$ & 0.01 & 0.07 & 25 & 66 & 10 & -2.1 & 0.2 & - \\
\hline $6 \mathrm{R}-1$ & 386.7 & 0.000 .00 & 0.00 & 0.01 & 0 & 21 & 79 & $\mathrm{bd}$ & bd & - \\
\hline $6 \mathrm{R}-1-72 \mathrm{G}$ & 386.7 & 0.000 .00 & 0.01 & 0.01 & 0 & 0 & 100 & bd & bd & - \\
\hline 6R-2-129B & 388.8 & $\begin{array}{lll}0.00 & 0.00\end{array}$ & 0.01 & 0.01 & 0 & 15 & 85 & bd & bd & - \\
\hline $9 G$ & 88.8 & $\begin{array}{lll}0.00 & 0.05\end{array}$ & 0.02 & 0.06 & $\mathbf{0}$ & 73 & 27 & bd & -2.7 & - \\
\hline 10R1-65B & 415.5 & 0.000 .00 & 0.00 & 0.00 & 0 & 89 & 11 & $\mathrm{bd}$ & -0.7 & bd \\
\hline 10R1-65G & 415.5 & 0.000 .04 & 0.00 & 0.04 & 0 & 95 & 5 & bd & bd & 1.1 \\
\hline $12 \mathrm{R}-1-28 \mathrm{G}$ & 429.2 & 0.000 .05 & 0.03 & 0.07 & 0 & 64 & 36 & bd & -0.8 & - \\
\hline 14R-1-11B & 434.1 & $\begin{array}{ll}0.02 & 0.00\end{array}$ & 0.01 & 0.03 & 67 & 12 & 21 & -9.3 & -13.7 & - \\
\hline 14R-1-11G & 434.1 & $\begin{array}{lll}0.00 & 0.07\end{array}$ & 0.01 & 0.08 & $\mathbf{0}$ & 92 & 8 & $\mathrm{bd}$ & -5.7 & - \\
\hline $14 R-1-65 B$ & 434.7 & 0.000 .03 & 0.01 & 0.05 & 0 & 75 & 25 & bd & -9.9 & - \\
\hline $14 \mathrm{R}-1-65 \mathrm{G}$ & 434.7 & 0.000 .01 & 0.01 & 0 & 0 & 5 & 47 & $\mathrm{bd}$ & -0.9 & - \\
\hline 14R-1-65P & 434.7 & 0.040 .38 & 0.01 & 0.44 & 10 & 87 & 3 & -4.1 & -1.7 & - \\
\hline 15R4-142B & 449.5 & 0.000 .00 & 0.01 & 0.01 & 0 & 37 & 63 & $\mathrm{bd}$ & -0.9 & -4.2 \\
\hline $15 \mathrm{R} 4-142 \mathrm{G}$ & 49.5 & $0.00 \quad 0.07$ & 0.00 & 0.07 & 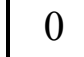 & 95 & 5 & bd & -8.4 & -4.3 \\
\hline $15 \mathrm{R} 4-142 \mathrm{P}$ & & $0.00 \quad 0.37$ & 0.00 & 0.37 & 0 & 99 & 1 & bd & -1.9 & -4.6 \\
\hline 17R-1-70G & 462.1 & $\begin{array}{lll}0.04 & 0.00\end{array}$ & 0.01 & 0.05 & 71 & 5 & 24 & -2.7 & bd & - \\
\hline 19R-1-41B & 476.5 & $\begin{array}{ll}0.01 & 0.01\end{array}$ & 0.01 & 0.02 & 26 & 30 & & -0.5 & -4.4 & - \\
\hline $19 R-1-41 G$ & 476.5 & 0.020 .08 & 0.04 & 0.14 & 11 & 57 & 32 & -3.5 & -2.9 & - \\
\hline 20R-1-57M & 481.2 & $\begin{array}{ll}0.01 & 0.00\end{array}$ & 0.01 & 0.02 & 57 & 3 & 39 & $-\mathbf{0 . 9}$ & bd & - \\
\hline 23R1-66B & 500.6 & 0.000 .01 & 0.01 & 0.02 & 0 & 42 & 58 & bd & -0.5 & -3.9 \\
\hline 23R1-66G & 500.6 & 0.000 .03 & 0.00 & 0.03 & 0 & 90 & 10 & bd & -1.3 & -6.5 \\
\hline 23R-2-21G & 501.6 & $\begin{array}{lll}0.02 & 0.01\end{array}$ & 0.01 & 0.04 & 52 & 29 & 20 & bd & -2.1 & - \\
\hline 23R-2-66B & 502.0 & 0.000 .00 & 0.00 & 0.01 & 21 & 49 & 31 & bd & -0.8 & - \\
\hline 23R-2-66G & 502.0 & $\begin{array}{ll}0.01 & 0.01\end{array}$ & 0.01 & 0.03 & 26 & 33 & 40 & -0.7 & -5.1 & - \\
\hline 23R-2-66P & 502.0 & 0.000 .03 & 0.01 & 0.04 & 6 & 61 & 33 & bd & -9.6 & - \\
\hline 24R1-117G & 507.1 & 0.000 .09 & 0.01 & 0.10 & 2 & 86 & 12 & -0.2 & -0.5 & -5.2 \\
\hline $25 R-1-123 B$ & 510.7 & $\begin{array}{ll}0.00 & 0.01\end{array}$ & 0.00 & 0.01 & 14 & 48 & 38 & bd & -1.5 & - \\
\hline $25 \mathrm{R}-1-123 \mathrm{G}$ & 510.7 & 0.000 .01 & 0.02 & 0.03 & 10 & 27 & 62 & bd & -5.2 & - \\
\hline 25R-1-123P & $|510.7|$ & 0.000 .02 & 0.01 & 0.03 & 12 & 61 & 27 & bd & -3.4 & - \\
\hline
\end{tabular}




\begin{tabular}{|l|c|ccc:c|ccc|ccc|} 
26R-1-76G & $\mathbf{5 1 6 . 3}$ & $\mathbf{0 . 0 5}$ & $\mathbf{0 . 0 7}$ & $\mathbf{0 . 0 1}$ & $\mathbf{0 . 1 3}$ & $\mathbf{4 1}$ & $\mathbf{5 0}$ & $\mathbf{9}$ & $\mathbf{- 1 . 2}$ & $\mathbf{- 0 . 9}$ & - \\
30R1-119G & 536.4 & 0.00 & 0.00 & 0.01 & 0.01 & 0 & 35 & 21 & bd & 0.3 & 1.2 \\
30R1-119B & 536.4 & 0.00 & 0.00 & 0.00 & 0.00 & 0 & 42 & 8 & bd & -0.1 & -0.1 \\
32R-3-50B & 553.4 & 0.00 & 0.01 & 0.01 & 0.01 & 1 & 54 & 45 & bd & -4.2 & - \\
32R-3-50G & 553.4 & 0.03 & 0.03 & 0.02 & 0.08 & 34 & 42 & 24 & -1.6 & -1.4 & - \\
34R2-82B & 562.9 & 0.00 & 0.00 & 0.00 & 0.00 & 0 & 0 & 21 & bd & bd & 0.6 \\
34R2-82G & 562.9 & 0.00 & 0.00 & 0.00 & 0.00 & 0 & 0 & 8 & bd & bd & 0.0 \\
36R-1-53B & 573.7 & 0.00 & 0.01 & 0.00 & 0.01 & 0 & 68 & 32 & bd & -1.7 & - \\
36R-1-53G & 573.7 & 0.01 & 0.02 & 0.01 & 0.03 & 21 & 51 & 28 & -1.5 & 0.1 & - \\
\hline
\end{tabular}


Table S3. Listing of individual $\delta^{34} \mathrm{~S}$ measurements by SIMS and laser ablation. In cases where only one measurement was made per granule, the $\delta^{34} \mathrm{~S}$-pyrite and mean $\delta^{34} \mathrm{~S}$ per pyrite granule are identical. All $\delta^{34} \mathrm{~S}$ are in \% versus VCDT. Samples in bold were also used for DNA extractions.

\begin{tabular}{|c|c|c|c|c|c|c|c|}
\hline $\begin{array}{c}\text { Analy } \\
\text { sis } \\
\text { Type }\end{array}$ & Core ID & $\begin{array}{l}\text { Depth } \\
\text { (mbsf) }\end{array}$ & $\begin{array}{c}\text { Granule } \\
\text { ID }\end{array}$ & $\begin{array}{c}\text { Granule } \\
\text { Subsample } \\
\text { ID }\end{array}$ & $\delta^{34} S$ & $\begin{array}{l}\text { Standard } \\
\text { deviation }\end{array}$ & $\begin{array}{c}\text { Mean } \\
\delta^{34} \mathbf{S}\end{array}$ \\
\hline laser & 13R-1 & 430.8 & 13 & $\mathrm{a}$ & -46.4 & 0.2 & -46.4 \\
\hline laser & $13 \mathrm{R}-1$ & 430.8 & 1 & $\mathrm{a}$ & -40.5 & 0.3 & -45.3 \\
\hline laser & $13 \mathrm{R}-1$ & 430.8 & 1 & $\mathrm{~b}$ & -51.3 & 0.2 & \\
\hline laser & $13 \mathrm{R}-1$ & 430.8 & 1 & $\mathrm{c}$ & -45.3 & 0.2 & \\
\hline laser & 13R-1 & 430.8 & 1 & $\mathrm{~d}$ & -32.2 & 0.2 & \\
\hline laser & 13R-1 & 430.8 & 1 & $\mathrm{e}$ & -50.6 & 0.3 & \\
\hline laser & 13R-1 & 430.8 & 1 & $\mathrm{f}$ & -51.0 & 0.3 & \\
\hline laser & $13 \mathrm{R}-1$ & 430.8 & 1 & $\mathrm{~g}$ & -46.0 & 0.3 & \\
\hline laser & 13R-1 & 430.8 & 1 & $\mathrm{~h}$ & -45.3 & 0.2 & \\
\hline laser & 13R-1 & 430.8 & 2 & $\mathrm{a}$ & -2.4 & 0.2 & -2.4 \\
\hline laser & $13 \mathrm{R}-1$ & 430.8 & 3 & $\mathrm{a}$ & -3.9 & 0.2 & -3.9 \\
\hline laser & $13 \mathrm{R}-1$ & 430.8 & 4 & $\mathrm{a}$ & -3.4 & 0.2 & -3.4 \\
\hline laser & 13R-1 & 430.8 & 5 & $\mathrm{a}$ & -3.4 & 0.2 & -3.3 \\
\hline laser & 13R-1 & 430.8 & 5 & $\mathrm{~b}$ & -3.4 & 0.3 & \\
\hline laser & 13R-1 & 430.8 & 5 & $\mathrm{c}$ & -3.1 & 0.2 & \\
\hline laser & 13R-1 & 430.8 & 6 & $\mathrm{a}$ & -3.4 & 0.2 & -3.3 \\
\hline laser & $13 \mathrm{R}-1$ & 430.8 & 6 & $\mathrm{~b}$ & -3.2 & 0.2 & \\
\hline laser & 13R-1 & 430.8 & 7 & $\mathrm{a}$ & -3.5 & 0.2 & -3.8 \\
\hline laser & 13R-1 & 430.8 & 7 & $\mathrm{~b}$ & -4.2 & 0.2 & \\
\hline laser & $13 \mathrm{R}-1$ & 430.8 & 8 & $\mathrm{a}$ & -3.9 & 0.2 & -3.9 \\
\hline laser & 13R-1 & 430.8 & 9 & $\mathrm{a}$ & -3.7 & 0.2 & -3.7 \\
\hline laser & 13R-1 & 430.8 & 10 & $\mathrm{a}$ & -4.6 & 0.2 & -4.6 \\
\hline laser & 13R-1 & 430.8 & 11 & $\mathrm{a}$ & -5.6 & 0.2 & -5.6 \\
\hline laser & 13R-1 & 430.8 & 12 & $\mathrm{a}$ & -5.9 & 0.2 & -5.4 \\
\hline laser & $13 \mathrm{R}-1$ & 430.8 & 12 & $b$ & -5.2 & 0.2 & \\
\hline laser & $13 \mathrm{R}-1$ & 430.8 & 12 & $\mathrm{c}$ & -5.1 & 0.2 & \\
\hline laser & 14R-1-11 & 434.7 & 1 & $\mathbf{a}$ & -23.5 & 0.3 & -25.8 \\
\hline laser & 14R-1-11 & 434.7 & 1 & b & -28.1 & 0.2 & \\
\hline laser & 14R-1-11 & 434.7 & 2 & $\mathbf{a}$ & -22.9 & 0.2 & -21.7 \\
\hline laser & 14R-1-11 & 434.7 & 2 & $\mathbf{b}$ & -20.4 & 0.2 & \\
\hline laser & 14R-1-11 & 434.7 & 3 & $\mathbf{a}$ & 0.4 & 0.2 & 0.3 \\
\hline laser & 14R-1-11 & 434.7 & 3 & b & 0.8 & 0.2 & \\
\hline laser & 14R-1-11 & 434.7 & 3 & c & -0.2 & 0.2 & \\
\hline laser & 14R-1-11 & 434.7 & 4 & $\mathbf{a}$ & 0.3 & 0.2 & 0.5 \\
\hline laser & 14R-1-11 & 434.7 & 4 & $\mathbf{b}$ & 0.7 & 0.2 & \\
\hline laser & 14R-1-11 & 434.7 & 5 & $\mathbf{a}$ & -0.2 & 0.2 & -0.2 \\
\hline laser & 14R-1-11 & 434.7 & 6 & $\mathbf{a}$ & -29.9 & 0.4 & -32.2 \\
\hline
\end{tabular}




\begin{tabular}{|c|c|c|c|c|c|c|c|}
\hline laser & 14R-1-11 & 434.7 & 6 & b & -34.4 & 0.3 & \\
\hline laser & 14R-1-11 & 434.7 & 7 & $\mathbf{a}$ & -33.8 & 0.2 & -35.2 \\
\hline laser & 14R-1-11 & 434.7 & 7 & b & -36.5 & 0.3 & \\
\hline laser & 14R-1-11 & 434.7 & 8 & $\mathbf{a}$ & 0.4 & 0.2 & 0.7 \\
\hline laser & 14R-1-11 & 434.7 & 8 & $\mathbf{b}$ & 1.1 & 0.2 & \\
\hline laser & 14R-1-11 & 434.7 & 9 & $\mathbf{a}$ & -46.6 & 0.2 & -29.8 \\
\hline laser & 14R-1-11 & 434.7 & 9 & b & -13.0 & 0.2 & \\
\hline laser & 14R-1-11 & 434.7 & 10 & $\mathbf{a}$ & -7.7 & 0.2 & -7.7 \\
\hline laser & 14R-1-11 & 434.7 & 11 & $\mathbf{a}$ & -4.9 & 0.2 & -4.9 \\
\hline laser & 14R-1-11 & 434.7 & 12 & $\mathbf{a}$ & -8.7 & 0.3 & -8.7 \\
\hline laser & 14R-1-11 & 434.7 & 13 & $\mathbf{a}$ & -9.0 & 0.3 & -9.0 \\
\hline sims & 14R-1-11 & 434.7 & 14 & $\mathbf{a}$ & -10.4 & 0.5 & -10.4 \\
\hline sims & 14R-1-11 & 434.7 & 15 & $\mathbf{a}$ & -3.3 & 0.7 & -3.3 \\
\hline sims & 14R-1-11 & 434.7 & 16 & $\mathbf{a}$ & -19.4 & 0.6 & -19.4 \\
\hline laser & $15 \mathrm{R}-2$ & 445.9 & 1 & $\mathrm{a}$ & -7.4 & 0.2 & -7.2 \\
\hline laser & $15 \mathrm{R}-2$ & 445.9 & 1 & $\mathrm{~b}$ & -10.0 & 0.2 & \\
\hline laser & $15 \mathrm{R}-2$ & 445.9 & 1 & $\mathrm{c}$ & -10.0 & 0.2 & \\
\hline laser & $15 \mathrm{R}-2$ & 445.9 & 1 & $\mathrm{~d}$ & -1.2 & 0.2 & \\
\hline laser & $15 \mathrm{R}-2$ & 445.9 & 2 & $\mathrm{a}$ & -0.9 & 0.2 & -0.9 \\
\hline laser & $15 \mathrm{R}-2$ & 445.9 & 3 & $\mathrm{a}$ & -1.1 & 0.2 & -1.1 \\
\hline laser & $15 \mathrm{R}-2$ & 445.9 & 4 & $\mathrm{a}$ & -1.7 & 0.2 & -1.7 \\
\hline laser & $15 \mathrm{R}-2$ & 445.9 & 5 & $\mathrm{a}$ & -8.2 & 0.2 & -8.2 \\
\hline laser & $15 \mathrm{R}-2$ & 445.9 & 6 & $\mathrm{a}$ & -19.3 & 0.2 & -19.3 \\
\hline laser & $15 \mathrm{R}-2$ & 445.9 & 7 & $\mathrm{a}$ & -3.8 & 0.2 & -8.6 \\
\hline laser & $15 \mathrm{R}-2$ & 445.9 & 7 & $\mathrm{~b}$ & -8.2 & 0.2 & \\
\hline laser & $15 \mathrm{R}-2$ & 445.9 & 7 & $\mathrm{c}$ & -6.0 & 0.4 & \\
\hline laser & $15 \mathrm{R}-2$ & 445.9 & 7 & $\mathrm{~d}$ & -16.3 & 0.2 & \\
\hline laser & $15 \mathrm{R}-2$ & 445.9 & 8 & $\mathrm{a}$ & -2.4 & 0.2 & -2.4 \\
\hline laser & $15 \mathrm{R}-2$ & 445.9 & 9 & $\mathrm{a}$ & -3.2 & 0.2 & -3.2 \\
\hline laser & $15 \mathrm{R}-2$ & 445.9 & 10 & $\mathrm{a}$ & -4.2 & 0.2 & -4.2 \\
\hline laser & $15 \mathrm{R}-2$ & 445.9 & 11 & $\mathrm{a}$ & -13.8 & 0.2 & -13.8 \\
\hline laser & $15 \mathrm{R}-2$ & 445.9 & 12 & $\mathrm{a}$ & -1.9 & 0.2 & -1.9 \\
\hline laser & $15 \mathrm{R}-2$ & 445.9 & 13 & $\mathrm{a}$ & -1.6 & 0.2 & -1.6 \\
\hline laser & $15 \mathrm{R}-2$ & 445.9 & 14 & $\mathrm{a}$ & -9.7 & 0.2 & -9.7 \\
\hline sims & $15 \mathrm{R}-2$ & 445.9 & 1 & $\mathrm{a}$ & -0.3 & 0.3 & -0.3 \\
\hline sims & $15 \mathrm{R}-2$ & 445.9 & 2 & $\mathrm{a}$ & -2.9 & 0.3 & -2.9 \\
\hline sims & $15 \mathrm{R}-2$ & 445.9 & 3 & $\mathrm{a}$ & -25.9 & 0.3 & -25.9 \\
\hline sims & $15 \mathrm{R}-2$ & 445.9 & 4 & $\mathrm{a}$ & -22.6 & 0.3 & -22.6 \\
\hline sims & $15 \mathrm{R}-2$ & 445.9 & 5 & $\mathrm{a}$ & -1.6 & 0.4 & -1.6 \\
\hline sims & $15 \mathrm{R}-2$ & 445.9 & 6 & $\mathrm{a}$ & -11.7 & 0.5 & -11.7 \\
\hline sims & $15 \mathrm{R}-2$ & 445.9 & 7 & $\mathrm{a}$ & -17.5 & 0.4 & -17.5 \\
\hline sims & $15 \mathrm{R}-2$ & 445.9 & 8 & $\mathrm{a}$ & -7.9 & 0.5 & -7.9 \\
\hline sims & $15 \mathrm{R}-2$ & 445.9 & 9 & $\mathrm{a}$ & -2.7 & 0.5 & -2.7 \\
\hline sims & $15 \mathrm{R}-2$ & 445.9 & 10 & $\mathrm{a}$ & -1.9 & 0.5 & -1.9 \\
\hline sims & $15 \mathrm{R}-2$ & 445.9 & 11 & $\mathrm{a}$ & -5.7 & 0.5 & -5.7 \\
\hline laser & $15 \mathrm{R}-4$ & 449.5 & 1 & $\mathrm{a}$ & -1.8 & 0.2 & -1.8 \\
\hline
\end{tabular}




\begin{tabular}{|c|c|c|c|c|c|c|c|}
\hline laser & $15 \mathrm{R}-4$ & 449.5 & 1 & $b$ & -1.7 & 0.2 & \\
\hline laser & $15 \mathrm{R}-4$ & 449.5 & 2 & $\mathrm{a}$ & -1.3 & 0.2 & -1.3 \\
\hline laser & $15 R-4$ & 449.5 & 3 & $\mathrm{a}$ & -1.4 & 0.2 & -1.5 \\
\hline laser & $15 \mathrm{R}-4$ & 449.5 & 3 & $\mathrm{~b}$ & -1.6 & 0.2 & \\
\hline laser & 17R-1-70 & 461.8 & 1 & $\mathbf{a}$ & -65.1 & 0.2 & -65.1 \\
\hline laser & 17R-1-70 & 461.8 & 2 & $\mathbf{a}$ & -69.0 & 0.2 & -69.4 \\
\hline laser & 17R-1-70 & 461.8 & 2 & b & -70.1 & 0.2 & \\
\hline laser & 17R-1-70 & 461.8 & 2 & c & -69.4 & 0.2 & \\
\hline laser & 17R-1-70 & 461.8 & 2 & d & -69.0 & 0.2 & \\
\hline laser & 17R-1-70 & 461.8 & 4 & $\mathbf{a}$ & -63.4 & 0.3 & -63.4 \\
\hline laser & 17R-1-70 & 461.8 & 5 & $\mathbf{a}$ & -68.5 & 0.2 & -68.5 \\
\hline laser & $17 R-1-70$ & 461.8 & 6 & $\mathbf{a}$ & -35.2 & 0.2 & -35.2 \\
\hline sims & 17R-1-70 & 461.8 & 7 & $\mathbf{a}$ & -70.4 & 0.4 & -70.4 \\
\hline sims & 17R-1-70 & 461.8 & 8 & $\mathbf{a}$ & -72.4 & 0.4 & -72.4 \\
\hline $\operatorname{sims}$ & 17R-1-70 & 461.8 & 9 & $\mathbf{a}$ & -71.2 & 0.5 & -71.2 \\
\hline $\operatorname{sims}$ & 17R-1-70 & 461.8 & 10 & $\mathbf{a}$ & -71.5 & 0.3 & -71.5 \\
\hline sims & 17R-1-70 & 461.8 & 11 & $\mathbf{a}$ & -58.6 & 0.4 & -58.6 \\
\hline laser & $18 \mathrm{R}-2$ & 473.1 & 1 & $\mathrm{a}$ & -31.0 & 0.2 & -30.1 \\
\hline laser & $18 \mathrm{R}-2$ & 473.1 & 1 & $\mathrm{~b}$ & -29.1 & 0.3 & \\
\hline laser & $18 \mathrm{R}-2$ & 473.1 & 2 & $\mathrm{a}$ & -14.0 & 0.3 & -9.9 \\
\hline laser & $18 \mathrm{R}-2$ & 473.1 & 2 & $\mathrm{~b}$ & -5.9 & 0.3 & \\
\hline laser & $18 \mathrm{R}-2$ & 473.1 & 3 & $\mathrm{a}$ & -0.2 & 0.2 & -13.1 \\
\hline laser & $18 \mathrm{R}-2$ & 473.1 & 3 & $\mathrm{~b}$ & -25.5 & 0.3 & \\
\hline laser & $18 \mathrm{R}-2$ & 473.1 & 3 & $\mathrm{c}$ & -0.9 & 0.2 & \\
\hline laser & $18 \mathrm{R}-2$ & 473.1 & 3 & $d$ & -18.0 & 0.7 & \\
\hline laser & $18 \mathrm{R}-2$ & 473.1 & 3 & e & -20.9 & 0.3 & \\
\hline laser & $18 \mathrm{R}-2$ & 473.1 & 4 & $\mathrm{a}$ & -1.4 & 0.2 & -4.9 \\
\hline laser & $18 \mathrm{R}-2$ & 473.1 & 4 & $\mathrm{~b}$ & -8.4 & 0.2 & \\
\hline laser & $18 \mathrm{R}-2$ & 473.1 & 5 & $\mathrm{a}$ & -7.7 & 0.4 & -3.5 \\
\hline laser & $18 \mathrm{R}-2$ & 473.1 & 5 & $\mathrm{~b}$ & 0.8 & 0.2 & \\
\hline laser & $18 \mathrm{R}-2$ & 473.1 & 6 & $\mathrm{a}$ & -15.9 & 0.2 & -13.8 \\
\hline laser & $18 \mathrm{R}-2$ & 473.1 & 6 & $\mathrm{~b}$ & -11.8 & 0.2 & \\
\hline laser & $18 \mathrm{R}-2$ & 473.1 & 7 & $\mathrm{a}$ & 1.2 & 0.3 & 0.7 \\
\hline laser & $18 \mathrm{R}-2$ & 473.1 & 7 & $\mathrm{~b}$ & 0.2 & 0.2 & \\
\hline laser & 19R-1 & 476.5 & 2 & $\mathrm{a}$ & -47.0 & 0.2 & -47.8 \\
\hline laser & 19R-1 & 476.5 & 2 & $\mathrm{~b}$ & -51.2 & 0.2 & \\
\hline laser & 19R-1 & 476.5 & 2 & $\mathrm{c}$ & -45.2 & 0.2 & \\
\hline laser & $19 \mathrm{R}-1$ & 476.5 & 3 & $\mathrm{a}$ & -61.7 & 0.2 & -62.5 \\
\hline laser & 19R-1 & 476.5 & 3 & $\mathrm{~b}$ & -63.3 & 0.2 & \\
\hline laser & 19R-1 & 476.5 & 4 & $\mathrm{a}$ & -62.1 & 0.4 & -62.1 \\
\hline laser & 19R-1 & 476.5 & 5 & $\mathrm{a}$ & -64.3 & 0.2 & -64.3 \\
\hline laser & $19 \mathrm{R}-1$ & 476.5 & 6 & $\mathrm{a}$ & -47.2 & 0.2 & -47.2 \\
\hline sims & $19 \mathrm{R}-1$ & 476.5 & 7 & $\mathrm{a}$ & -62.8 & 0.3 & -62.8 \\
\hline sims & 19R-1 & 476.5 & 8 & $\mathrm{a}$ & -65.7 & 0.5 & -65.7 \\
\hline sims & 19R-1 & 476.5 & 9 & $\mathrm{a}$ & -66.8 & 0.4 & -66.8 \\
\hline sims & 19R-1 & 476.5 & 10 & $\mathrm{a}$ & -66.7 & 0.6 & -66.7 \\
\hline
\end{tabular}




\begin{tabular}{|lllrlrlc|} 
sims & 19R-1 & 476.5 & 11 & $\mathrm{a}$ & -47.0 & 0.9 & -47.0 \\
sims & $19 \mathrm{R}-1$ & 476.5 & 12 & $\mathrm{a}$ & -61.9 & 0.5 & -61.9 \\
sims & $19 \mathrm{R}-1$ & 476.5 & 13 & $\mathrm{a}$ & -42.5 & 0.4 & -42.5 \\
\hline laser & $\mathbf{2 3 R}-2-21$ & $\mathbf{5 0 1 . 4}$ & $\mathbf{1}$ & $\mathbf{a}$ & $\mathbf{- 2 . 7}$ & $\mathbf{0 . 2}$ & $\mathbf{- 2 . 2}$ \\
laser & $\mathbf{2 3 R - 2 - 2 1}$ & $\mathbf{5 0 1 . 4}$ & $\mathbf{1}$ & $\mathbf{b}$ & $\mathbf{- 1 . 6}$ & $\mathbf{0 . 2}$ & \\
& & & & & & & \\
\hline
\end{tabular}


Table S4. Summary of $\delta^{13} \mathrm{C}$-TOC and TOC content data. $n$ indicates the number of subsamples analyzed. Values of individual subsamples are indicated in italic, where more than 1 subsample was analyzed. $\delta^{13} \mathrm{C}$-values are expressed in \%o vs. VPDB, TOC content in wt. $\%$ of total basalt. [* = same sample also used for genetic analyses; - = not determined; $\mathrm{G}=$ grey host rock, $\mathrm{B}=$ black halo.]

\begin{tabular}{|l|l|l|l|l|}
\hline Core ID & $\boldsymbol{n}$ & Depth (mbsf) & $\boldsymbol{\delta}^{\mathbf{1 3}} \mathbf{C}( \pm$ SD) & Wt. $\%$ \\
\hline $2 \mathrm{R}-3-93$ & 1 & 361.0 & -21.6 & - \\
\hline $2 \mathrm{R}-3-115$ & 1 & 361.3 & -26.6 & 0.017 \\
\hline $2 \mathrm{R}-3-134$ & 1 & 361.4 & -23.7 & 0.027 \\
\hline $4 \mathrm{R}-2-45 \mathrm{~B}$ & 1 & 368.6 & -34.0 & 0.025 \\
\hline $4 \mathrm{R}-2-45 \mathrm{G}$ & 1 & 368.6 & -34.6 & 0.019 \\
\hline $5 \mathrm{R}-2-126$ (mean) & 4 & 379.1 & $-32.6 \pm 0.4$ & $0.024( \pm 0.001)$ \\
$5 R-2-126 a$ & & & -32.8 & 0.025 \\
$5 R-2-126 b$ & & & -32.8 & 0.024 \\
$5 R-2-126 c$ & & & -32.0 & 0.024 \\
$5 R-2-126 d$ & & & -32.8 & 0.024 \\
\hline $14 \mathrm{R}-1-11$ (mean)* & 4 & 434.1 & $-23.8 \pm 2.0$ & $0.039( \pm 0.009)$ \\
$14 R-1-11 a$ & & & -26.5 & 0.031 \\
$14 R-1-11 b$ & & & -24.0 & 0.032 \\
$14 R-1-11 c$ & & & -21.9 & 0.050 \\
$14 R-1-11 d$ & & & -22.6 & 0.044 \\
\hline $15 \mathrm{R}-4-142$ (mean) & 4 & 443.6 & $-27.9 \pm 0.4$ & $0.048( \pm 0.025)$ \\
$15 R-4-142 a$ & & & -28.4 & 0.024 \\
$15 R-4-142 b$ & & & -27.9 & 0.049 \\
$15 R-4-142 c$ & & & -27.9 & 0.036 \\
$15 R-4-142 d$ & & & -27.5 & 0.083 \\
\hline $17 \mathrm{R}-1-70$ (mean)* & 3 & 462.1 & $-26.9 \pm 0.8$ & $0.031( \pm 0.006)$ \\
$17 R-1-70 a$ & & & -27.6 & 0.026 \\
$17 R-1-70 b$ & & & -27.2 & 0.029 \\
$17 R-1-70 c$ & & & -26.0 & 0.038 \\
\hline $23 \mathrm{R}-2-21^{*}$ & 1 & 499.9 & -33.5 & 0.020 \\
\hline $26 \mathrm{R}-1-76 *$ & 1 & 515.5 & -33.9 & 0.019 \\
\hline & & & \\
\hline
\end{tabular}


Table S5. Overview of $\delta^{13} \mathrm{C}$-carbonate values. All measurements expressed in \%o vs. VPDB.

\begin{tabular}{|l|c|r|}
\hline Sample & Depth (mbsf) & $\boldsymbol{\delta}^{\mathbf{1 3}} \mathbf{C}$ \\
\hline 5R-3-47 & 379.8 & 0.06 \\
12R-1-28 & 429.2 & -1.78 \\
18R-2-27 & 472.6 & -5.07 \\
18R-2-34 & 472.6 & -4.68 \\
18R-2-55 & 472.9 & -4.06 \\
18R-3-16 & 473.7 & -3.87 \\
18R-3-49 & 474.1 & -2.80 \\
18R-3-88 & 474.4 & -3.36 \\
18R-3-106 & 474.6 & -3.49 \\
18R-3-118 & 474.7 & -1.74 \\
18R-4-0 & 474.9 & -2.97 \\
18R-4-9 & 475.0 & -3.94 \\
35R-2-49 & 565.6 & -1.78 \\
\hline
\end{tabular}


Table S6. Compilation of $\delta^{13} \mathrm{C}$-isotopic fractionations from carbon dioxide $\left(\mathrm{CO}_{2}\right)$ to cell biomass across known $\mathrm{C}$-fixation pathways. Data compiled from seven different studies $(26,39-44)$ and references within. All data from pure cultures except where marked with an asterisk - asterisks indicate measurements on natural samples. Pathway means and standard deviations were determined on strain averages, where more than one published value was available. $\mathrm{PP}=$ pentose phosphate cycle (Calvin Benson Bassham Cycle), 3-H =3-hydroxypropionate cycle, $\mathrm{rTCA}=$ reverse tricarboxylic acid cycle, $\mathrm{rAP}=$ reductive acetyl CoA pathway, $\varepsilon_{\mathrm{CO} 2}$ to cells $=\mathrm{C}$-isotopic fractionation from $\mathrm{CO}_{2}$ to cell biomass, $\mathrm{N}$ $/ \mathrm{A}=$ not applicable. 


\begin{tabular}{|c|c|c|c|c|c|c|c|}
\hline \multirow[b]{2}{*}{ Count } & \multirow[b]{2}{*}{$\begin{array}{l}\text { Path- } \\
\text { way }\end{array}$} & \multirow[b]{2}{*}{ Organism } & \multirow[b]{2}{*}{$\begin{array}{l}T_{\text {growth }} \\
\left({ }^{\circ} \mathrm{C}\right)\end{array}$} & \multicolumn{3}{|l|}{$\varepsilon_{\mathrm{CO} 2 \text {-cell }}$} & \\
\hline & & & & $\begin{array}{l}\text { strain } \\
(\% 0)\end{array}$ & $\begin{array}{l}\text { strain } \\
\text { mean } \\
(\%)\end{array}$ & $\begin{array}{l}\text { strain } \\
\text { SD } \\
(\% \text { ) }\end{array}$ & Ref \\
\hline 1 & PP & Agmenellum quadrupicatum & 39 & 15.9 & 20.4 & 3.5 & 26 \\
\hline 2 & PP & " & 39 & 22.2 & & & 26 \\
\hline 3 & PP & " & 39 & 23.9 & & & 26 \\
\hline 4 & PP & " & 39 & 19.6 & & & 26 \\
\hline 5 & PP & Alkaligenes eutrophus & 28 & 28.2 & 28.2 & & 26 \\
\hline 6 & PP & Anacystis nidulans & 39 & 13.1 & 17.3 & 3.1 & 26 \\
\hline 7 & PP & " & 39 & 18 & & & 26 \\
\hline 8 & PP & " & 33 & 16 & & & 26 \\
\hline 9 & PP & " & 33 & 21.5 & & & 26 \\
\hline 10 & PP & " & 33 & 18 & & & 26 \\
\hline 11 & PP & Rhodopseudomonas capsulata & & 10.8 & 10.4 & & 26 \\
\hline 12 & PP & " & 30 & 9.9 & & & 26 \\
\hline 13 & PP & Thiobacillus novellus* & 30 & 5.1 & 5.1 & & 39 \\
\hline 14 & PP & Thiobacillus neapolitanus* & & 25.8 & 25.8 & & 26 \\
\hline 15 & PP & Thiocapsa roseopersicina* & 28 & 22 & 22.0 & & 26 \\
\hline 16 & PP & Thiomicrospira sp. L-12* & & 25.5 & 25.5 & & 26 \\
\hline 17 & PP & Thiomicrospira crunogena* & & 24.5 & 24.5 & & 26 \\
\hline 18 & PP & Thiomicrospira crunogena* & & 23.3 & 23.3 & & 26 \\
\hline 19 & PP & Chlamydomonas reinhardtii* & 20 & 36.8 & 36.8 & & 26 \\
\hline 20 & PP & Microcoleus chthonoplastes & 39 & 17.1 & 17.1 & & 26 \\
\hline 21 & PP & Schizothrix calcicola & 39 & 13.2 & 13.2 & & 26 \\
\hline 22 & PP & Synechococcus sp. & 57 & 22.5 & 17.8 & 2.0 & 26 \\
\hline 23 & PP & " & & 15.5 & & & 26 \\
\hline 24 & PP & " & & 16.4 & & & 26 \\
\hline 25 & PP & " & & 18.6 & & & 26 \\
\hline 26 & PP & " & & 18.6 & & & 26 \\
\hline 27 & PP & " & & 17.2 & & & 26 \\
\hline 28 & PP & " & & 17.1 & & & 26 \\
\hline 29 & PP & " & & 15.6 & & & 26 \\
\hline 30 & PP & " & & 16.9 & & & 26 \\
\hline 31 & PP & " & & 18.9 & & & 26 \\
\hline 32 & PP & " & & 18.1 & & & 26 \\
\hline 33 & PP & Synechococcus lividus & 47 & 12.8 & 12.0 & & 26 \\
\hline 34 & PP & " & 70 & 11.1 & & & 26 \\
\hline 35 & PP & Chlorella sorokiniana & 39 & 22.6 & 22.6 & & 26 \\
\hline 36 & PP & Chromatium tepidum & 50 & 20.5 & 20.5 & & 26 \\
\hline
\end{tabular}




\begin{tabular}{|c|c|c|c|c|c|c|}
\hline 37 & PP & Chromatium strain D* & 20 & 31 & 31.9 & \\
\hline 38 & PP & * & 20 & 32.7 & & \\
\hline 39 & PP & Chromatium vinosum* & 20 & 27.3 & 27.3 & \\
\hline 40 & PP & Coccochloris elebens & 39 & 12.3 & 14.2 & \\
\hline 41 & PP & " & 39 & 16 & & \\
\hline 42 & PP & Nitrosomonas europaea* & & 13.8 & 15.7 & 3.8 \\
\hline 43 & PP & " & & 13.2 & & \\
\hline 44 & PP & " & & 20 & & \\
\hline 45 & PP & Oscillatoria williamsii & 39 & 5 & 11.2 & \\
\hline 46 & PP & " & 39 & 17.3 & & \\
\hline 47 & PP & Oscillochloris trichoides* & 28 & 20.1 & 20.1 & \\
\hline 48 & PP & Rhodospirillum rubrum & 20 & 21.1 & 16.9 & \\
\hline 49 & PP & " & 20 & 12.7 & & \\
\hline 50 & $3-\mathrm{H}$ & Acidianus brierleyi & 65 & 3.6 & 3.6 & \\
\hline 51 & $3-\mathrm{H}$ & Metallosphaera sedula & 65 & 3.1 & 0.7 & 3.3 \\
\hline 52 & $3-\mathrm{H}$ & " & 65 & -3 & & \\
\hline 53 & $3-\mathrm{H}$ & $"$ & 65 & 2 & & \\
\hline 54 & $3-\mathrm{H}$ & Nitrosopumilus maritimus & & 20 & 20.0 & \\
\hline 55 & $3-\mathrm{H}$ & Sulfolobus solfataricus & 85 & 0.2 & 0.2 & \\
\hline 56 & rTCA & Aquifex aeolicus & 85 & 5.4 & 5.4 & \\
\hline 57 & rTCA & Chlorobium limicola & 30 & 9.5 & 9.5 & \\
\hline 58 & rTCA & Chlorobium phaeovibrioides* & 30 & 10.4 & 10.0 & \\
\hline 59 & rTCA & " & 30 & 9.5 & & \\
\hline 60 & rTCA & Chlorobium thiosulfatophilum* & 20 & 20.1 & 20.1 & \\
\hline 61 & rTCA & Chlorobium vibrioforme* & 30 & 12.2 & 11.3 & 0.7 \\
\hline 62 & rTCA & " & 30 & 10.8 & & \\
\hline 63 & rTCA & " & 30 & 10.7 & & \\
\hline 64 & rTCA & " & 28 & 11.4 & & \\
\hline 65 & rTCA & Chloroflexus aurantiacus & 55 & 7.6 & 11.9 & 2.9 \\
\hline 66 & rTCA & " & 55 & 13.7 & & \\
\hline 67 & rTCA & " & 55 & 12.7 & & \\
\hline 68 & rTCA & " & 55 & 13.6 & & \\
\hline 69 & rTCA & Desulfobacter hydrogenophilus & 28 & 10 & 12.5 & 3.0 \\
\hline 70 & rTCA & " & 28 & 8.9 & & \\
\hline 71 & rTCA & $"$ & 28 & 14.2 & & \\
\hline 72 & rTCA & $"$ & 28 & 13.7 & & \\
\hline 73 & rTCA & " & 30 & 15.9 & & \\
\hline 74 & rTCA & Hydrogenobacter thermophilus & 70 & 5.5 & 5.5 & \\
\hline 75 & rTCA & Pyrobaculum aerophilum & 100 & 2.9 & 2.9 & \\
\hline 76 & rTCA & Thermocrinis ruber & 85 & 3.3 & 3.3 & \\
\hline 77 & rTCA & Thermoproteus neutrophilus & 85 & 2 & 5.4 & \\
\hline 78 & rTCA & $"$ & & 8.7 & & \\
\hline 79 & rTCA & Pyrodictium occultum & 102 & 2.3 & 2.3 & \\
\hline
\end{tabular}




\begin{tabular}{|c|c|c|c|c|c|c|c|}
\hline 80 & rTCA & Pyrolobus fumarii & 105 & 3.8 & 3.8 & & 39 \\
\hline 81 & rAP & Desulfotomaculum acetoxidans & 30 & 30.5 & 29.5 & & 42 \\
\hline 82 & rAP & " & 30 & 28.5 & & & 43 \\
\hline 83 & rAP & Desulfobacterium autotrophicum & 28 & 39.3 & 24.3 & 16.7 & 26 \\
\hline 84 & rAP & " & 28 & 38.2 & & & 26 \\
\hline 85 & rAP & " & 30 & 10 & & & 42 \\
\hline 86 & rAP & " & & 9.6 & & & 43 \\
\hline 87 & rAP & Archaeoglobus fulgidus & 85 & 2.7 & 4.3 & & 39 \\
\hline 88 & rAP & $"$ & 85 & 5.8 & & & 39 \\
\hline 89 & rAP & Archaeoglobus lithotrophicus & 85 & 8 & 8.0 & & 39 \\
\hline 90 & rAP & Ferroglobus placidus & 85 & 3.5 & 3.5 & & 39 \\
\hline 91 & rAP & Acetobacterium woodii & 28 & 22.2 & 22.3 & 6.6 & 26 \\
\hline 92 & rAP & " & 28 & 29 & & & 26 \\
\hline 93 & rAP & " & 28 & 15.8 & & & 26 \\
\hline 94 & rAP & M.bacterium thermoautotrophicum & 65 & 12.7 & 25.9 & 9.9 & 44 \\
\hline 95 & rAP & " & 65 & 26.6 & & & 44 \\
\hline 96 & rAP & " & 65 & 43.8 & & & 44 \\
\hline 97 & rAP & " & 65 & 46 & & & 44 \\
\hline 98 & rAP & " & 65 & 24.5 & & & 44 \\
\hline 99 & rAP & " & 65 & 21.9 & & & 44 \\
\hline 100 & rAP & " & 65 & 23.1 & & & 44 \\
\hline 101 & rAP & " & 65 & 15 & & & 39 \\
\hline 102 & rAP & " & 65 & 19.1 & & & 26 \\
\hline 103 & rAP & " & 56 & 27 & & & 44 \\
\hline 104 & rAP & " & 56 & 26.6 & & & 44 \\
\hline 105 & rAP & " & 66 & 27.4 & & & 44 \\
\hline 106 & rAP & " & & 34 & & & 44 \\
\hline 107 & rAP & " & 65 & 15 & & & 39 \\
\hline 108 & rAP & Methanobacterium formicicum & 34 & 36.1 & 36.4 & 1.9 & 44 \\
\hline 109 & rAP & " & 34 & 38.4 & & & 44 \\
\hline 110 & rAP & " & 34 & 34.7 & & & 44 \\
\hline 111 & rAP & Methanobacterium sp. & 37 & 25.1 & 22.9 & 2.8 & 26 \\
\hline 112 & rAP & " & 37 & 23.2 & & & 26 \\
\hline 113 & rAP & " & 46 & 18.8 & & & 26 \\
\hline 114 & rAP & " & 46 & 24.5 & & & 26 \\
\hline 115 & rAP & M.bacterium sp. strain Ivanov & 37 & 25.2 & 22.8 & 3.0 & 44 \\
\hline 116 & rAP & " & 37 & 23.2 & & & 44 \\
\hline 117 & rAP & " & 46 & 18.5 & & & 44 \\
\hline 118 & rAP & $"$ & 46 & 24.3 & & & 44 \\
\hline 119 & rAP & M.bacterium strain M.o.H. & 40 & 11.5 & 11.5 & & 44 \\
\hline 120 & rAP & M.caldococcus jannaschii & 85 & 6.2 & 12.1 & 4.9 & 39 \\
\hline 121 & rAP & " & 85 & 17.7 & & & 39 \\
\hline 122 & rAP & " & 85 & 10.7 & & & 39 \\
\hline
\end{tabular}




\begin{tabular}{|c|c|c|c|c|c|c|}
\hline 123 & rAP & " & 85 & 13.7 & & \\
\hline 124 & rAP & Methanococcus igneus & 85 & 20.2 & 21.5 & \\
\hline 125 & rAP & M.coccus thermolithotrophicus & 65 & 22.7 & 18.6 & 7.6 \\
\hline 126 & rAP & " & 65 & 25.8 & & \\
\hline 127 & rAP & " & 65 & 26.7 & & \\
\hline 128 & rAP & " & 41 & 7.4 & & \\
\hline 129 & rAP & " & 51 & 13.5 & & \\
\hline 30 & rAP & " & 60 & 19.7 & & \\
\hline 31 & rAP & " & 65 & 24.8 & & \\
\hline 32 & rAP & " & 65 & 26 & & \\
\hline 33 & rAP & " & 70 & 24.9 & & \\
\hline 34 & rAP & " & 65 & 8.7 & & \\
\hline 35 & rAP & " & 45 & 20.5 & & \\
\hline 136 & rAP & " & 45 & 13.4 & & \\
\hline 137 & rAP & " & 45 & 4.8 & & \\
\hline 138 & rAP & " & 65 & 22 & & \\
\hline 139 & rAP & Methanopyrus kandleri & 100 & 20.3 & 16.5 & \\
\hline 140 & rAP & " & 100 & 12.7 & & \\
\hline 141 & rAP & Methanosarcina barkeri & 37 & 19.5 & 16.3 & 2.3 \\
\hline 142 & rAP & " & 40 & 14.8 & & \\
\hline 143 & rAP & " & 37 & 14.6 & & \\
\hline 144 & rAP & " & 37 & 16.3 & & \\
\hline 145 & rAP & Methanothermus fervidus & 85 & 13.1 & 13.1 & \\
\hline
\end{tabular}


Table S7. Mean $\delta^{13} \mathrm{C}$-isotopic fractionations from $\mathrm{CO}_{2}$ to cell biomass $\left(\varepsilon_{\mathrm{CO} 2 \text {-cells }}\right)$ in microbes using the reductive acetyl CoA pathway, calculated from compiled data in Table S6.

\begin{tabular}{|c|c|c|c|c|}
\hline \multirow[b]{2}{*}{ Taxon } & \multirow[b]{2}{*}{ Energy metabolism } & \multicolumn{2}{|c|}{$\varepsilon_{\mathrm{CO} 2 \text {-cells }}(\%)$} & \multirow[b]{2}{*}{ Ref. } \\
\hline & & mean & $\mathrm{SD}$ & \\
\hline Desulfotomaculum acetoxidans & $\mathrm{SO}_{4}{ }^{2-}$ reducer, $\mathrm{H}_{2} / \mathrm{CO}_{2}$ & 29.5 & & $\begin{array}{l}42-43 \\
26\end{array}$ \\
\hline Desulfobacterium autotrophicum & $\mathrm{SO}_{4}{ }^{2-}$ reducer, $\mathrm{H}_{2} / \mathrm{CO}_{2}$ & 24.3 & 16.7 & $42-43$ \\
\hline Archaeoglobus fulgidus & $\mathrm{SO}_{4}{ }^{2-}$ reducer, $\mathrm{H}_{2} / \mathrm{CO}_{2}$ & 4.3 & & 39 \\
\hline Archaeoglobus lithotrophicus & $\mathrm{SO}_{4}{ }^{2-}$ reducer, $\mathrm{H}_{2} / \mathrm{CO}_{2}$ & 8.0 & & 39 \\
\hline Ferroglobus placidus & $\mathrm{Fe}^{3+}, \mathrm{NO}_{3}^{-}, \mathrm{S}_{2} \mathrm{O}_{3}{ }^{2-}$ reducer & 3.5 & & 39 \\
\hline Acetobacterium woodii & acetogenesis, $\mathrm{H}_{2} / \mathrm{CO}_{2}$ & 22.3 & 6.6 & $\begin{array}{l}26 \\
42-43\end{array}$ \\
\hline M.bacterium thermoautotrophicum & methanogenesis, $\mathrm{H}_{2} / \mathrm{CO}_{2}$ & 25.9 & 9.9 & $26,39,44$ \\
\hline Methanobacterium formicicum & methanogenesis, $\mathrm{H}_{2} / \mathrm{CO}_{2}$ & 36.4 & 1.9 & 44 \\
\hline Methanobacterium sp. & methanogenesis, $\mathrm{H}_{2} / \mathrm{CO}_{2}$ & 22.9 & 2.8 & 26 \\
\hline Methanobacterium sp. strain Ivanov & methanogenesis, $\mathrm{H}_{2} / \mathrm{CO}_{2}$ & 22.8 & 3.0 & 44 \\
\hline Methanobacterium strain M.o.H. & methanogenesis, $\mathrm{H}_{2} / \mathrm{CO}_{2}$ & 11.5 & & 44 \\
\hline Methanocaldococcus jannaschii & methanogenesis, $\mathrm{H}_{2} / \mathrm{CO}_{2}$ & 12.1 & 4.9 & 39 \\
\hline Methanococcus igneus & methanogenesis, $\mathrm{H}_{2} / \mathrm{CO}_{2}$ & 21.5 & & 39 \\
\hline
\end{tabular}


Table S8. Media composition for initial enrichment and transfer. The composition, including the trace element and vitamin solutions, follows the methanogenic Medium 141 (DSMZ) except where indicated in bold. 2 atm headspace pressure of $80 \% \mathrm{H}_{2}: 20 \% \mathrm{CO}_{2}$ were applied. The final $\mathrm{pH}$ was adjusted to 8.0 . All incubations were at $65^{\circ} \mathrm{C}$.

\begin{tabular}{|c|c|c|}
\hline & Initial Enrichment & Transfer \\
\hline Ingredients of Medium & Quantity $\mathbf{L}^{-1}$ & Quantity $L^{-1}$ \\
\hline $\mathrm{KCl}$ & $0.34 \mathrm{~g}$ & $0.34 \mathrm{~g}$ \\
\hline $\mathrm{MgCl}_{2} \times 6 \mathrm{H}_{2} \mathrm{O}$ & $4.0 \mathrm{~g}$ & $6.85 \mathrm{~g}$ \\
\hline $\mathrm{MgSO}_{4} \times 7 \mathrm{H}_{2} \mathrm{O}$ & $3.45 \mathrm{~g}$ & omitted \\
\hline $\mathrm{NH}_{4} \mathrm{Cl}$ & $0.25 \mathrm{~g}$ & $0.25 \mathrm{~g}$ \\
\hline $\mathrm{CaCl}_{2} \times 2 \mathrm{H}_{2} \mathrm{O}$ & $0.14 \mathrm{~g}$ & $0.14 \mathrm{~g}$ \\
\hline $\mathrm{K}_{2} \mathrm{HPO}_{4}$ & $0.14 \mathrm{~g}$ & $0.14 \mathrm{~g}$ \\
\hline $\mathrm{NaCl}$ & $18.0 \mathrm{~g}$ & $18.0 \mathrm{~g}$ \\
\hline $\mathrm{Fe}\left(\mathrm{NH}_{4}\right)_{2}\left(\mathrm{SO}_{4}\right)_{2} \times 7 \mathrm{H}_{2} \mathrm{O}$ & $2 \mathrm{mg}$ & $2 \mathrm{mg}$ \\
\hline $\mathrm{NaHCO}_{3}$ & $2.5 \mathrm{~g}(29.8 \mathrm{mM})$ & $2.500 \mathrm{~g}(29.8 \mathrm{mM})$ \\
\hline Na-acetate & $0.082 \mathrm{~g}(1 \mathrm{mM})$ & $0.164 \mathrm{~g}(2 \mathrm{mM})$ \\
\hline Methanol stock (300 mM) & $0.17 \mathrm{~mL}(50 \mu \mathrm{M})$ & $1 \mathrm{~mL}(300 \mu \mathrm{M})$ \\
\hline Dimethyl sulfide stock $(30 \mathrm{mM})$ & $1.67 \mathrm{~mL}(50 \mu \mathrm{M})$ & $10 \mathrm{~mL}(300 \mu \mathrm{M})$ \\
\hline Yeast extract (Difco) & $0.20 \mathrm{~g}$ & $0.200 \mathrm{~g}$ \\
\hline Trypticase (BBL) & $2.00 \mathrm{~g}$ & $2.00 \mathrm{~g}$ \\
\hline Resazurin & $1 \mathrm{mg}$ & $1 \mathrm{mg}$ \\
\hline Cysteine- $\mathrm{HCl} \times \mathrm{H}_{2} \mathrm{O}$ & $0.50 \mathrm{~g}$ & $0.50 \mathrm{~g}$ \\
\hline $\mathrm{Na}_{2} \mathrm{~S} \times 9 \mathrm{H}_{2} \mathrm{O}$ & $0.50 \mathrm{~g}$ & $0.50 \mathrm{~g}$ \\
\hline Trace elements & $10 \mathrm{~mL}$ & $10 \mathrm{~mL}$ \\
\hline Vitamin solution & $10 \mathrm{~mL}$ & $10 \mathrm{~mL}$ \\
\hline Distilled water, added to: & $1000 \mathrm{~mL}$ & $1000 \mathrm{~mL}$ \\
\hline
\end{tabular}


Table S9. Basalt media composition after 7 years (initial) and 5 years $\left(1^{\text {st }}\right.$ transfer $)$ of incubation. bd = below detection; $\delta^{13} \mathrm{C}$-values in \%o vs. VPDB.

\begin{tabular}{|c|c|c|c|c|c|c|c|}
\hline \multirow[b]{2}{*}{ Core ID } & \multirow[b]{2}{*}{ Replicate } & \multirow[b]{2}{*}{ enrichment } & \multicolumn{4}{|c|}{ Aqueous concentrations } & \multirow{2}{*}{$\begin{array}{l}\delta^{13} \mathrm{C} \\
(\%) \\
\mathrm{CH}_{4}\end{array}$} \\
\hline & & & $\begin{array}{c}\mathrm{CH}_{4} \\
(\mu \mathrm{M})\end{array}$ & $\begin{array}{c}\mathrm{SO}_{4}{ }^{2-} \\
(\mathbf{m M})^{1}\end{array}$ & $\begin{array}{c}\mathrm{H}_{2} \mathrm{~S} \\
(\mathrm{mM})^{2}\end{array}$ & $\begin{array}{c}\text { DIC } \\
(\mathbf{m M})^{3}\end{array}$ & \\
\hline $1 \mathrm{R}-1-79$ & $A$ & initial & 0.0 & 17.0 & $\mathrm{bd}$ & 20.1 & -62 \\
\hline $1 \mathrm{R}-1-79$ & $\mathrm{~B}$ & initial & 0.0 & 17.3 & $\mathrm{bd}$ & 26.9 & -64 \\
\hline 14R-1-11 & A & initial & $0.1 \pm 0.0$ & 17.4 & $\mathrm{bd}$ & 27.4 & -52 \\
\hline $1 \mathrm{R}-1-79$ & $A$ & 1st transfer & $0.7 \pm 0.3$ & 8.0 & $\mathrm{bd}$ & 1.4 & -54 \\
\hline $1 \mathrm{R}-1-79$ & $\mathrm{~B}$ & 1st transfer & $1.6 \pm 0.3$ & 8.4 & $\mathrm{bd}$ & 2.4 & $-62^{4}$ \\
\hline 14R-1-11 & A & 1st transfer & 1.5 & 7.4 & $\mathrm{bd}$ & 2.2 & $-62^{4}$ \\
\hline $23 R-2-21$ & $A$ & 1st transfer & $0.7 \pm 0.5$ & 7.7 & $\overline{b d}$ & 3.3 & -65 \\
\hline
\end{tabular}

1) initial concentration: $15.3 \mathrm{mM}$ in original enrichment medium, $1.3 \mathrm{mM}$ in transfer medium.

2) initial concentration: $2.1 \mathrm{mM}$

3) initial concentration: $\geq 29.8 \mathrm{mM}$

4) average of duplicate measurements with precision of $\pm 1.5 \%$. 
Table S10. (A) Mean molar content of the potential electron donors Fe(II), S (AVS+CRS), and OC per liter of basalt. (B) Mean molar content of the potential electron acceptors $\mathrm{Fe}(\mathrm{III}), \mathrm{SO}_{4}$, and IC per liter of basalt. All molar contents were calculated from mean weight percentages of Fe, S, and $\mathrm{C}$ fractions in host rock, and are from this study (Tables S2, S4, S13) except where indicated by footnotes. Molar contents of bulk data were converted from per gram to per liter assuming a basalt density of $2,750 \mathrm{~g} \mathrm{~L}^{-1}$, which is the mean bulk density of basalt at U1301B (calculated from (9)). Molar contents of aqueous species (DOC, sulfate $(a q)$, DIC) were calculated assuming a porosity of $5.3 \%$, which is the mean porosity at U1301B (calculated from (9)), by multiplying mean concentrations from basement fluids sampled from boreholes or BBS by a factor of 0.053 . These values are rough estimates since they assume that concentrations of basement fluids from boreholes or BBS fully reflect those within veins and basaltic pore space. CRS was assumed to be $100 \%$ pyrite $\left(\mathrm{FeS}_{2}\right)$. Abbreviations: FTT $=$ FischerTropsch-type, $\mathrm{SR}=$ sulfate reduction, $\mathrm{MG}=$ methanogenesis, $\mathrm{AG}=$ acetogenesis, Fe-red $=\mathrm{Fe}(\mathrm{III})$ reduction, $\mathrm{FMT}=$ fermentation, $\mathrm{ND}=$ not determined, $\mathrm{N} / \mathrm{A}=$ not applicable (sample size $<3$ ).

(A)

\begin{tabular}{|c|c|c|c|}
\hline \multirow[t]{2}{*}{$e^{-}$-donor } & \multicolumn{2}{|c|}{ mol L $^{-1}$ basalt } & \multirow[t]{2}{*}{ Potential energy-yielding reactions } \\
\hline & Mean & SD & \\
\hline $\mathbf{F e}(\mathrm{II})^{1}$ & $2.5 \mathrm{E}+00$ & $2.5 \mathrm{E}-01$ & \multirow{2}{*}{$\begin{array}{l}\text { Indirect; biotic SR, MG, } \mathrm{AG}, \mathrm{Fe}-\mathrm{red} \text { from }(\mathrm{a}) \mathrm{H}_{2} \text { produced by } \\
\text { serpentinization and/or (b) small organic molecules produced by } \\
\text { FTT synthesis }\end{array}$} \\
\hline Olivine $^{1,2}$ & $9.1 \mathrm{E}-01$ & $1.2 \mathrm{E}+00$ & \\
\hline $\mathbf{S}(\mathrm{AVS}+\mathrm{CRS})$ & $3.3 \mathrm{E}-02$ & $2.7 \mathrm{E}-02$ & \multirow{3}{*}{$\begin{array}{l}\text { Indirect; biotic } \mathrm{S}^{0} \text { disproportionation of } \mathrm{S} \text { species, e.g. produced } \\
\text { by abiotic } \mathrm{S}^{2-} \text { oxidation with } \mathrm{Fe}(\mathrm{III})\end{array}$} \\
\hline AVS & $7.1 \mathrm{E}-03$ & $1.2 \mathrm{E}-02$ & \\
\hline CRS & $2.6 \mathrm{E}-02$ & $2.3 \mathrm{E}-02$ & \\
\hline TOC & $6.2 \mathrm{E}-02$ & $2.4 \mathrm{E}-02$ & Biotic SR, MG, AG; AOM, FMT \\
\hline $\mathrm{DOC}^{3}$ & $6.6 \mathrm{E}-7$ & $\mathrm{~N} / \mathrm{A}$ & Biotic SR, MG, AG; AOM, FMT \\
\hline
\end{tabular}

(B)

\begin{tabular}{|c|c|c|}
\hline$e^{-}$-acceptor & mol L $\mathrm{L}^{-1}$ basalt & Potential energy-yielding reactions \\
\hline & Mean & \\
\hline $\mathbf{F e}(\mathrm{IIII})^{1}$ & $1.1 \mathrm{E}+00 \quad 3.7 \mathrm{E}-01$ & $\begin{array}{l}\text { Abiotic } \mathrm{Fe}(\mathrm{III}) \text { reduction by reactions with } \mathrm{S}^{2-} \text { may restore } \\
\text { bioavailable inorganic } \mathrm{S} \text { species; biotic Fe-red }\end{array}$ \\
\hline $\begin{array}{r}\text { Sulfate (total) } \\
\text { Sulfate }(a q)^{4} \\
\end{array}$ & $\begin{array}{cc}9.5 \mathrm{E}-03 & 8.0 \mathrm{E}-03 \\
1.0 \mathrm{E}-03 & \mathrm{~N} / \mathrm{A}\end{array}$ & $\begin{array}{l}\text { Biotic SR, AOM } \\
\text { Biotic SR, AOM }\end{array}$ \\
\hline $\begin{array}{l}\text { IC } \\
\mathrm{DIC}^{5}\end{array}$ & $\begin{array}{l}\mathrm{ND} \quad \mathrm{ND} \\
2.0 \mathrm{E}-06 \quad \mathrm{~N} / \mathrm{A}\end{array}$ & $\begin{array}{l}\text { Biotic MG, AG } \\
\text { Biotic MG, AG }\end{array}$ \\
\hline
\end{tabular}

${ }^{1}$ individual values (in wt \%) shown in Table S11.

2 averaged from 9 .

${ }^{3}$ assumes $12.5 \mu \mathrm{M}$ concentration, which is the average from 1026B and BBS (6).

${ }^{4}$ assumes $17.6 \mathrm{mM}$, which is value measured in U1301A borehole fluid (11).

${ }^{5}$ assumes $37.5 \mu \mathrm{M}$, which is the average from 1026B and BBS (10). 
Table S11. $\mathrm{Fe}^{2+}, \mathrm{Fe}^{2+}$-olivine, $\mathrm{Fe}^{3+}$, and FeTotal (FeT) content in host rock and halos (halos in parentheses) at borehole U1301B. All data from this study, except $\mathrm{Fe}^{2+}$-olivine data, which was calculated from bulk olivine measurements published in reference 9 .

\begin{tabular}{|c|c|c|c|c|c|}
\hline \multirow[b]{2}{*}{$\begin{array}{l}\text { Sample } \\
\text { ID }\end{array}$} & \multirow[b]{2}{*}{$\begin{array}{l}\text { Depth } \\
\text { (mbsf) }\end{array}$} & \multicolumn{4}{|c|}{ weight $\%$} \\
\hline & & $\mathrm{Fe}^{2+}$ & $\begin{array}{l}\mathrm{Fe}^{2+}- \\
\text { olivine }\end{array}$ & $\mathrm{Fe}^{3+}$ & FeT \\
\hline 1R-1-14 & 351.3 & & $\mathrm{bd}$ & & \\
\hline 1R-1-79 & 352 & 4.8 & & 3.5 & 8.3 \\
\hline $1 \mathrm{R}-1-118$ & 352.4 & & trace & & \\
\hline 2R-1-4 & 357.1 & & 0.7 & & \\
\hline 2R-2-98 & 359.6 & 5.4 & & 2.3 & 7.7 \\
\hline $4 R-4-7$ & 371.2 & 5.3 & & 2.5 & 7.8 \\
\hline $5 R-1-22$ & 377.5 & 5.4 & & 1.9 & 7.4 \\
\hline $6 \mathrm{R}-2-129$ & 388.8 & $4.1(5.1)$ & & $2.0(4.5)$ & $6.1(9.6)$ \\
\hline $12 \mathrm{R}-1-31$ & 429.2 & & 5.5 & & \\
\hline $14 \mathrm{R}-1-11$ & 434.1 & $5.6(5.7)$ & & $1.7(3.5)$ & $7.3(9.2)$ \\
\hline $15 R-4-66$ & 448.8 & & trace & & \\
\hline $16 \mathrm{R}-1-83$ & 454.0 & & 2.2 & & \\
\hline $17 R-1-70$ & 462.1 & $4.4(5.5)$ & & $2.2(3.8)$ & $6.5(9.3)$ \\
\hline $18 R-2-92$ & 473.2 & & 7.7 & & \\
\hline 19R-1-41 & 476.5 & $5.2(5.1)$ & & $1.8(3.7)$ & $6.9(8.9)$ \\
\hline 19R-1-132 & 477.4 & & 1.7 & & \\
\hline $20 R-1-57$ & 481.2 & 5.0 & & 3.7 & 8.7 \\
\hline $21 \mathrm{R}-2-126$ & 493.0 & & 0.9 & & \\
\hline 23R-2-21 & 501.6 & $4.8(5.9)$ & & $1.5(1.8)$ & $6.3(7.8)$ \\
\hline $26 \mathrm{R}-1-41$ & 515.9 & & 1.1 & & \\
\hline $26 \mathrm{R}-1-76$ & 516.3 & $5.8(6.1)$ & & $1.5(2.3)$ & $7.3(8.4)$ \\
\hline $35 \mathrm{R}-2-107$ & 566.1 & & 0.8 & & \\
\hline 36R-2-102 & 575.7 & & 1.7 & & \\
\hline
\end{tabular}


Table S12. List of $d s r A B / d s r B$ primers tested in study. $x d s r B=$ xenologous $d s r B, r d s r B=$ reverse $d s r B$.

\begin{tabular}{|c|c|c|c|}
\hline Primer & Sequence $\left(5^{\prime}-3^{\prime}\right)$ & Target groups & Reference \\
\hline Dsr-1F & ACS CAC TGG AAG CAC G & General & 14 \\
\hline Dsr-4R & GTG TAG CAG TTA CCG CA & General & 14 \\
\hline Dsr 1F1 & CAG GAY GAR CTK CAC CG & General & 20 \\
\hline Dsr 1R1 & CCC TGG GTR TGR AYR AT & General & 20 \\
\hline Del1075R & GYT CVC GGT TCT TDC & $\delta$ Proteobacteria & 45 \\
\hline Arch1830F & TGC TGT CNA ACA TG & Archaeoglobales & 45 \\
\hline AG dsrF & GAG AGA GGA GCA ACR & Archaeoglobales & This study \\
\hline AG-FC dsrR & TCG TCC CAC CAS TCC CA & Archaeoglobales, Firmicutes & This study \\
\hline dsrB F1a & CAC ACC CAG GGC TGG & General except $x d s r B$ & This study \\
\hline dsrB F1b & CAT ACT CAG GGC TGG & General except $x d s r B$ & This study \\
\hline dsrB F1c & CAT ACC CAG GGC TGG & General except $x d s r B$ & This study \\
\hline dsrB F1d & CAC ACT CAA GGT TGG & General except $x d s r B$ & This study \\
\hline dsrB F1e & CAC ACA CAG GGA TGG & General except $x d s r B$ & This study \\
\hline dsrB F1f & CAC ACG CAG GGA TGG & General except $x d s r B$ & This study \\
\hline dsrB F1g & CAC ACG CAG GGG TGG & General except $x d s r B$ & This study \\
\hline dsrB F1h & CAT ACG CAA GGT TGG & General except $x d s r B$ & This study \\
\hline dsrB F2a & CGT CCA CAC CCA GGG & $x d s r B$ & This study \\
\hline dsrB F2b & TGT GCA TAC CCA GGG & $x d s r B$ & This study \\
\hline dsrB F2c & CAT TCA TAC CCA GGG & $x d s r B$ & This study \\
\hline dsrB F2d & TGT TCA CAC CCA GGG & $x d s r B$ & This study \\
\hline dsrB F2e & CGT GCA CAC GCA GGG & $x d s r B$ & This study \\
\hline dsrB F2f & CGT TCA TAC ACA GGG & $x d s r B$ & This study \\
\hline dsrB F2g & TGT CCA CAC TCA GGG & $x d s r B$ & This study \\
\hline dsrB F2h & CGT GCA TAC GCA GGG & $x d s r B$ & This study \\
\hline dsrB F2i & CAT CCA TAC TCA GGG & $x d s r B$ & This study \\
\hline dsrB 4RSI1a & CAG TTA CCG CAG TAC AT & General except $x d s r B \quad \& r d s r B$ & This study \\
\hline dsrB 4RSI1b & CAG TTA CCG CAG AAC AT & General except $r d s r B$ & This study \\
\hline dsrB 4RSI1c & CAG TTG CCG CAG TAC AT & General except $x d s r B \& r d s r B$ & This study \\
\hline dsrB 4RSI1d & CAG TTT CCG CAG TAC AT & General except $x d s r B \& r d s r B$ & This study \\
\hline dsrB 4RSI1e & CAG TTG CCG CAG AAC AT & General except $r d s r B$ & This study \\
\hline dsrB 4RSI1f & CAG TTT CCA CAG AAC AT & General except $x d s r B \& r d s r B$ & This study \\
\hline dsrB 4RSI2a & CAG GCG CCG CAG CAG AT & $r d s r B$ & This study \\
\hline dsrB 4RSI2b & CAG GCG CCG CAG CAC AC & $r d s r B$ & This study \\
\hline dsrB 4RSI2c & CAT GCT CCG CAG CAG AT & $r d s r B$ & This study \\
\hline dsrB 4RSI2d & CAC GCG CCG CAA GCC AC & $r d s r B$ & This study \\
\hline dsrB 4RSI2e & CAT GCA CCA CAA CAA AT & $r d s r B$ & This study \\
\hline dsrB 4RSI2f & CAG GCA CCA CAG CAG AT & $r d s r B$ & This study \\
\hline dsrB 4RSI2g & CAG GCT CCG CAG CAG AT & $r d s r B$ & This study \\
\hline dsrB 4R & CAG GCG CCG CAG TAC AT & $r d s r B$ & This study \\
\hline
\end{tabular}


Table S13. PCR primer combination, target group, fragment size, and DNA extracts tested. For pure cultures, 40 amplification cycles were used except where indicated. Since 4 of the original 10 sample DNA extracts from Hole U1301B had been used up for $m c r A$ amplifications, only 6 DNA extracts could be checked for $d s r$ presence. Due to low remaining volumes of DNA extract, we first amplified residual basalt DNA extracts with the DSR1F / 4R primer pair in a $50 \mu \mathrm{L}-\mathrm{PCR}$-reaction volume for $40 \mathrm{PCR}$ cycles, and then used subsamples $(2 \mu \mathrm{L})$ for reamplifications in 40 cycles with the DSR1F / 4R primer pair, or nested PCR using other primer combinations. [Dsv. $=$ Desulfovibrio, Dsm. $=$ Desulfotomaculum, Ag. = Archaeoglobus.]

\begin{tabular}{|l|l|l|l|l|l|l|l|}
\hline Primer Combination & Target Group & $\begin{array}{l}\text { Size } \\
(\mathrm{bp})\end{array}$ & $\begin{array}{l}\text { Dsv. } \\
\text { ocea- } \\
\text { nii }\end{array}$ & $\begin{array}{l}\text { Dsm. } \\
\text { spp. } \\
\text { Eth2 }\end{array}$ & $\begin{array}{l}\text { Ag. } \\
\text { fulgi- } \\
\text { dus* }\end{array}$ & $\begin{array}{l}\text { Ag. } \\
\text { sulfati- } \\
\text { callidus }^{3}\end{array}$ & $\begin{array}{l}\text { U1301 } \\
\text { B }\end{array}$ \\
\hline DSR1F / 4R & General & $-1,900$ & + & + & + & & \\
\hline Dsr-1F1 / -1R1 & General & $-1,000$ & + & + & nd & nd & \\
\hline DSR1F / Del1075R & S Proteobacteria & -940 & + & nd & nd & nd & - \\
\hline Arch1830F / DSR4R & Archaeoglobales & -350 & nd & nd & - & & - \\
\hline AG dsrF / DSR4R & Archaeoglobales & $-1,100$ & nd & nd & + & & - \\
\hline Dsr-1F / AG-FC dsrR & Archaeoglobales, & -900 & nd & nd & + & + & - \\
\hline dsrB F1a-h / 4RSI1a- & General except & -350 & - & nd & + & + & + \\
\hline dsrB F2a-i / 4RSI1b,e & xdsrB & -350 & nd & + & nd & nd & - \\
\hline dsrB F1a-h / 4RSI2a- & rdsrB & -350 & nd & nd & nd & nd & - \\
\hline
\end{tabular}

${ }^{1}$ negative PCR result after 25 amplification cycles.

2 Isolate provided by Flemming Mønsted Christensen.

${ }^{3}$ Isolated from back rust deposit on borehole observatory at ODP Site 1026 (46). No published dsrAB sequence. 